NBER WORKING PAPER SERIES

THE INTERGENERATIONAL EFFECTS OF PARENTAL INCARCERATION

\author{
Will Dobbie \\ Hans Grönqvist \\ Susan Niknami \\ Mårten Palme \\ Mikael Priks \\ Working Paper 24186 \\ http://www.nber.org/papers/w24186 \\ NATIONAL BUREAU OF ECONOMIC RESEARCH
1050 Massachusetts Avenue
Cambridge, MA 02138
January 2018
}

We thank Manudeep Bhuller, Stephen Billings, Leah Platt Boustan, Hank Farber, Randi Hjalmarsson, Alan Krueger, Ilyana Kuziemko, Matthew Lindquist, Alex Mas, Joseph Murray, David Price, Torsten Santavirta, Christopher Wildeman, Crystal Yang, Owen Zidar, and numerous seminar participants for helpful comments and suggestions. Kevin DeLuca, Nicole Gandre, Disa Hynsjo, James Reeves, Amy Wickett, and numerous students in Sweden provided excellent research assistance. Ann-Sofie Arvidsson, Malcolm Pettersson, and many others provided invaluable help in answering our questions about the institutional context. Funding for this project was provided by FORTE and Handelsbankens forskningsstiftelser. The views expressed herein are those of the authors and do not necessarily reflect the views of the National Bureau of Economic Research.

NBER working papers are circulated for discussion and comment purposes. They have not been peer-reviewed or been subject to the review by the NBER Board of Directors that accompanies official NBER publications.

(C) 2018 by Will Dobbie, Hans Grönqvist, Susan Niknami, Mårten Palme, and Mikael Priks. All rights reserved. Short sections of text, not to exceed two paragraphs, may be quoted without explicit permission provided that full credit, including $\odot$ notice, is given to the source. 
The Intergenerational Effects of Parental Incarceration

Will Dobbie, Hans Grönqvist, Susan Niknami, Mårten Palme, and Mikael Priks

NBER Working Paper No. 24186

January 2018

JEL No. J13,J24,J62,K14,K42

\begin{abstract} poverty and criminal behavior, even in affluent countries with extensive social safety nets.

Will Dobbie

Industrial Relations Section

Louis A. Simpson International Bldg.

Princeton University

Princeton, NJ 08544-2098

and NBER

wdobbie@princeton.edu

Hans Grönqvist

Uppsala University and IFAU

Department of Economics

75120

Uppsala

Sweden

hans.gronqvist@nek.uu.se

Susan Niknami

Stockholm University

SOFI

10691

Stockholm

Sweden

susan.niknami@sofi.su.se

Mårten Palme

Department of Economics

Stockholm University

SE-106 91 Stockholm

SWEDEN

and IZA

Marten.Palme@ne.su.se

Mikael Priks

Department of Economics

Stockholm University

SE-106 91 Stockholm

SWEDEN

mikael.priks@ne.su.se
\end{abstract}

We estimate the causal effect of parental incarceration on children's medium-run outcomes using administrative data from Sweden. Our empirical strategy exploits exogenous variation in parental incarceration from the random assignment of criminal defendants to judges with different incarceration tendencies. We find that the incarceration of a parent in childhood leads to significant increases in teen crime and pregnancy and a significant decrease in early-life employment. The effects are concentrated among children from the most disadvantaged families, where teen crime increases by 18 percentage points, teen pregnancy increases by 8 percentage points, and employment at age 20 decreases by 28 percentage points. In contrast, there are no detectable effects among children from more advantaged families. These results imply that the incarceration of parents with young children may increase the intergenerational persistence of 
There has been a dramatic rise in the number of children growing up with an incarcerated parent. In the United States, for example, the proportion of children with an incarcerated father on any given day has nearly doubled over the last twenty-five years, increasing from $1.3 \%$ of children in 1990 to $2.2 \%$ of children in 2015 . The proportion of children with an incarcerated father has also roughly doubled in most European countries over this time period, albeit from a much lower level $\left.\right|^{1}$ Poor children are particularly likely to grow up with an incarcerated parent, with approximately $12.5 \%$ of low-income children in the United States having a parent incarcerated at some point during their childhood 2 These trends have fueled a long-standing debate on the causal effects of parental incarceration on children. Children growing up with an incarcerated parent fare worse than those without an incarcerated parent on a wide range of economic, behavioral, and educational outcomes (e.g., Murray, Farrington, and Sekol 2012). Existing studies, however, have been unable to separate the causal effects of parental incarceration from pre-existing risk factors such as living in an unstable or abusive home, attending a low-quality school, and growing up in a high-crime neighborhood (e.g., Wildeman and Western 2010).

In this paper, we estimate the causal effect of parental incarceration on children's medium-run outcomes in the context of the Swedish criminal justice system. Our work draws on two strengths of the Swedish setting. First, Swedish administrative data allow us to measure the impacts of parental incarceration for individuals who were between the ages of 11 and 14 at the time of their parent's trial and whose outcomes we observe in each year up to age 20. We observe a wide range of important outcomes in the data, including teen criminal convictions, teen pregnancies, high school graduation, welfare receipt at age 20, and formal sector earnings and employment at age 20. The second strength of our setting is that we are able to isolate exogenous variation in parental incarceration using the random assignment of defendants to judges who differ systematically in their stringency. We measure judge stringency using a leave-out measure based on all other cases that

\footnotetext{
${ }^{1}$ The available data suggest that the share of children with an incarcerated father in most European countries is about one-seventh the equivalent number in the United States in any given year, with slightly lower rates in the Nordic countries. The available data vary considerably across countries, however, with parental incarceration rates in many countries being imputed using the number of male prisoners and the likelihood of each prisoner being a father. See Wildeman and Western (2010) and Children of Prisoners Europe (2017) for additional details on these data for the United States and Europe, respectively.

${ }^{2}$ Low-income is defined as having a total household income below the federal poverty line. Information on the cumulative risk of parental incarceration, both overall and by subsample, is not available in most European countries. In our data, we find that approximately $6.5 \%$ of low-income children in Sweden have a parent incarcerated at some point during their childhood compared to only $1.9 \%$ of all children. In Denmark, Wildeman and Andersen (2015) similarly find that $1.5 \%$ of children experience paternal imprisonment, while $8.8 \%$ experience paternal incarceration when including jail stays of less than 24 hours. See Wildeman and Western (2010) and Murphey and Cooper (2015) for additional details on the U.S. data and Wildeman and Andersen (2015) for a comparison of the cumulative risks of paternal incarceration in the United States and other developed countries.
} 
a judge has handled during the same year. This leave-out stringency measure is highly predictive of parental incarceration decisions, but uncorrelated with case and family characteristics. Using our judge stringency measure as an instrumental variable (IV) for parental incarceration, we can identify the causal effect of parental incarceration for children whose parents are at the margin of incarceration compared to children whose parents were convicted but not incarcerated 3

Using this empirical strategy, we find that the assignment of a parent to a more stringent judge leads to significant increases in teen crime and pregnancy and a significant decrease in early-life employment. Under the stronger assumptions necessary to use judge stringency as an instrumental variable, we estimate that parental incarceration increases teen convictions by 9.9 percentage points (41.8\%), increases teen pregnancies by 6.0 percentage points $(200.0 \%)$, and decreases employment at age 20 by 16.5 percentage points $(23.7 \%)$. The only outcome that is not substantially impacted by parental incarceration in the full sample is high school graduation, which decreases by only a statistically insignificant 1.3 percentage points (3.4\%). We find larger effects for first-time cases and cases involving mothers, but large standard errors mean that not all of the differences are statistically significant. We also find that our instrumental variables estimates are systematically larger than the corresponding OLS estimates, suggesting that there are particularly large effects of parental incarceration for cases where judges disagree on the appropriate sentence.

The negative effects of parental incarceration on children are driven almost entirely by children from the most disadvantaged families. We measure family disadvantage using an index of baseline education, employment, criminal history, and drug and alcohol abuse for both biological parents. For children from the most disadvantaged families, parental incarceration increases teen convictions by 18.4 percentage points $(71.0 \%)$, increases teen pregnancies by 8.0 percentage points $(222.2 \%)$, and decreases employment at age 20 by 27.9 percentage points (41.8\%). By comparison, there are no detectable effects of parental incarceration among children from advantaged families for any of our outcomes. There is more suggestive evidence that the characteristics of the non-convicted parent are at least as important as those of the incarcerated parent, with the largest point estimates for children whose non-convicted parent has a criminal history or a history of drug and alcohol abuse. These findings add to a growing body of evidence that disadvantaged children are more sensitive

\footnotetext{
${ }^{3}$ Our IV strategy is similar to that used in prior work to estimate the intergenerational effects of parental DI receipt in Norway (Dahl, Kostøl, and Mogstad 2014) and the impact of incarceration on an individual's own outcomes in the United States (Mueller-Smith 2015) and Norway (Bhuller et al. 2016). In other related work using a randomjudge design, all from the United States, Kling (2006) estimates the impact of sentence length, Aizer and Doyle (2015) estimate the impact of juvenile incarceration, and Dobbie, Goldin, and Yang (forthcoming) estimate the impact of pre-trial incarceration.
} 
to shocks such as growing up in a bad neighborhood (e.g., Wilson 1996, Harding 2003, Wodtke, Elwert, and Harding 2016), parental job loss (Oreopoulos, Page, and Stevens 2008, Coelli 2011), parental death (Adda, Björklund, and Holmlund 2011), and parental EITC transfers (Dahl and Lochner 2012).

In sharp contrast to the results for children, the negative effects of incarceration on a parent's own outcomes are concentrated among the most advantaged families. For these households, incarceration decreases parental employment over the next six years by 24.5 percentage points (35.9\%) and the probability that the parent lives in a two-adult household by 45.8 percentage points (102.0\%). By comparison, there are small and imprecisely estimated effects of incarceration on parental employment and family structure among the most disadvantaged families, i.e., the families where the effects on children's outcomes are most concentrated. In other words, we find a negative correlation between the effects on children's outcomes and the effects on a parent's own outcomes across different samples, ${ }^{4}$

The results from our analysis suggest that the incarceration of parents with young children significantly increases the intergenerational persistence of poverty and criminal behavior, even in affluent countries with extensive social safety nets. Putting our results together, the negative effects of parental incarceration can be explained by the particular sensitivity of disadvantaged children to the trauma of having a parent sent to prison, not the increase in single-parent households or the loss of family income following an incarceration spell. These findings are consistent with recent work arguing that the negative effects of parental incarceration come from both the initial shock of losing a parent to prison and the cycle of imprisonment and release that often follows, not changes in economic resources or family structure (e.g., Wildeman 2010, Murray, Loeber, and Pardini 2012). Our findings are also consistent with recent evidence showing that positive wealth shocks have little effect on children's medium-run outcomes in either the United States (Jacob, Kapustin, and Ludwig 2015) or Sweden (Cesarini et al. 2016).

We conclude by using our new estimates to calculate the net social cost of parental incarceration. In our social cost calculation, we account for the costs of future child crime, pregnancy, and welfare receipt, the costs of future parental crime and welfare receipt, and the direct economic impacts on both parents and their children. We also account for the average number of children in each

\footnotetext{
${ }^{4}$ The null result of incarceration on parental employment among the most disadvantaged families may be partially due to floor effects, as only $29.8 \%$ of parents from these families are employed following an incarceration spell. These floor effects are unlikely to explain the effects on family structure, however, as $66.7 \%$ of parents from these families live in a two-adult household following an incarceration spell.
} 
family in our sample (2.767) and discount all benefits and costs back to the time of the trial using a discount rate of $3 \%$. We estimate that the social cost of parental incarceration at the margin is over $\$ 300,000$ per family, with just over half of these social costs coming from the effects on children's outcomes. In other words, we find that the costs of incarcerating a parent are roughly double the costs of incarcerating a non-parent.

These social cost estimates likely represent a lower bound on the costs of parental incarceration in settings such as the United States. The criminal justice system in Sweden is broadly similar to other Nordic countries, but considerably less punitive than the criminal justice systems in most other countries, including the United States. Like the other Nordic countries, Sweden also has a much more generous social welfare system than most other countries, likely ameliorating at least some of the adverse consequences of parental incarceration. Consistent with this theory, intergenerational correlations of both poverty and criminal behavior are weaker in Sweden than in other developed countries (e.g., Björklund and Jäntti 1997, Murray, Janson, and Farrington 2007).

Our results contribute to an important literature estimating the impact of parental incarceration on children's outcomes (see Wildeman and Western 2010 and Murray et al. 2012 for recent reviews). Parental incarceration has been linked to children's academic problems (e.g., Foster and Hagan 2007, Cho 2009a, Cho 2009b), infant mortality (e.g., Wildeman et al. 2014), behavioral and mental health problems (e.g., Murray and Farrington 2005, Wildeman 2010), and criminal behavior (e.g., Johnson 2009, Hjalmarsson and Lindquist 2011, Hjalmarsson and Lindquist 2012). Three recent papers go beyond these associations to estimate the causal effect of parental incarceration on children. Wildeman and Andersen (2016) find significant effects of paternal incarceration on the criminal behavior of boys, but not girls, using variation from a Danish reform that decreased the risk of incarceration for some crimes. Conversely, Billings (2017) finds that paternal incarceration decreases school behavioral problems in the United States after accounting for child fixed effects. Finally, Bhuller et al. (forthcoming) find imprecise effects of paternal incarceration on children's criminal activity and school performance in Norway using a random-judge design similar to our own.

This paper is also related to a large literature examining the determinants of youth crime and delinquent behavior. There are significant peer effects on youth criminal behavior within neighborhoods (e.g., Kling, Ludwig, and Katz 2005, Sciandra et al. 2013, Damm and Dustmann 2014), schools (e.g., Billings, Deming, and Rockoff 2013), and juvenile corrections facilities (e.g., Bayer, Hjalmarsson, and Pozen 2009). Criminal behavior among youth is also affected by educational attainment (e.g., Lochner and Moretti 2004, Anderson 2014, Hjalmarsson, Holmlund, and Lindquist 
2015, Cook and Kang 2016), school quality (e.g., Deming 2011, Dobbie and Fryer 2015), the home environment (e.g., Doyle 2008), birth order (e.g., Breining et al. 2017), and parental education (e.g., Meghir, Palme, and Schnabel 2012).

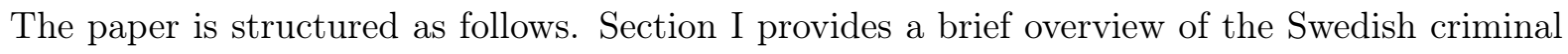
justice system, describes how criminal court cases are assigned to courtrooms, and compares the criminal justice systems in Sweden with other developed countries. Section [II describes our data and sample restrictions. Section III describes our empirical strategy. Section IV presents the results, Section $\mathrm{V}$ examines potential mechanisms, and Section VI concludes. An online appendix provides additional results.

\section{The Swedish Criminal Justice System}

In this section, we describe the aspects of the criminal justice system in Sweden that are most relevant for our study. We also discuss the most important differences between Sweden and other developed countries and how these differences may impact the external validity of our estimates.

\section{A. The Swedish Court System}

The criminal court system in Sweden consists of three levels: the district court, the court of appeals, and the supreme court. The vast majority of criminal cases are settled at the district court level, where each district court is generally responsible for all cases originating in its jurisdiction. In this paper, we focus on criminal cases tried in any of the 48 district courts in Sweden. Appendix Table A1 provides additional details on each of the district courts in our data. The largest district courts are located in large cities, such as Stockholm and Uppsala, and have 20 to 45 judges, while the smallest courts are located in more rural areas and only have a few judges.

District courts in Sweden are usually divided into divisions (avdelningar) and then sections (rotlar), although some small courts are only divided into sections. Each section consists of one professional judge, one clerk, and a number of administrative personnel. District court judges are appointed for life and can only lose their jobs if they are convicted of a serious crime. Prior to their appointment, district court judges must have a law degree but are not required to have any prior experience working in the court system. Each district court also maintains a large pool of politically-appointed lay jurors (nämndemän) that serve a similar function as juries in the American system. Each lay juror works approximately 10 to 15 days per year, with the assignment of lay jurors 
to both cases and judges being essentially random (Anwar, Bayer, and Hjalmarsson forthcoming) $!^{5}$

In most district court trials, both the verdict and sentence are decided by one professional judge and three lay jurors. Following the hearing, the judge summarizes the facts of the case and any relevant laws for the three lay jurors. The judge and three lay jurors then discuss the possible decisions, including the verdict and sentence. If the judge and the lay jurors disagree on the verdict, a vote is held to determine the outcome of the case. The votes of the judge and lay jurors have equal weight, but the judge holds the tiebreaker if there is no clear majority. If a defendant is found guilty, there is a second vote to determine the sentence, with the least severe option chosen if there is an even split between different sentencing options (e.g., probation rather than incarceration).

Appendix Figure A1 provides additional details on how suspected crimes are processed in Sweden's criminal justice system. If there is suspicion of a crime, then a preliminary investigation is undertaken by the police or a prosecutor. The prosecutor then decides whether the individual should be charged with a crime and whether the case should advance to a court trial ${ }^{6}$ Of these charged cases, $77 \%$ result in a court trial. The other charged cases are typically settled without a trial, usually because the suspect has confessed to a petty crime. A small number of charged crimes result in no prosecution, trial, or penalty, usually because the defendant is under 18 years of age. Once a case proceeds to trial, it is assigned to a judge in the relevant court. Of these court trials, $23 \%$ result in incarceration, $37 \%$ in a fine, $24 \%$ in probation, and in only $6 \%$ of cases, the defendant is found not guilty.

One important advantage of the Swedish criminal justice system compared to other countries is the absence of plea bargaining. In the United States, for example, criminal defendants often know the assigned judge before deciding whether to plead guilty to a charge in exchange for a reduced sentence, a process known as "bargaining under the shadow of the judge." The fact that these types of pre-trial agreements are not taking place in our setting simplifies the interpretation of our estimates using the assigned judge as an instrument for parental incarceration.

\footnotetext{
${ }^{5}$ Specifically, lay jurors indicate their availability for different fixed dates in the upcoming year (e.g., the first Monday of each month). Lay jurors are then assigned specific dates in advance of any knowledge about the cases to be tried on those dates. For each date, a court administrator then forms juror triplets, with some attempt to balance gender, age, and political party. Finally, the court coordinator assigns each juror triplet to a courtroom scheduled to be in session in a quasi-random fashion. See Anwar et al. (forthcoming) for additional details on lay jurors in Sweden.

${ }^{6}$ There are 32 local prosecution offices in Sweden. Within each office, there are a number of teams working on different types of crime. The allocation to a specific prosecutor within a team is based on time available and experience. Apart from the 32 local prosecution offices, four national offices work only special cases (e.g., corruption) and three national offices work only on international cases.
} 


\section{B. Assignment of Cases to Judges}

During our sample period, nearly all criminal cases were randomly allocated to the sections (and hence judges) within each district court by government decree (Förordning (1996:381) med tingsrättsinstruktion, §9). The random assignment of cases was meant to ensure that each section received an equal number of cases, with no consideration of the scope or complexity of the case. The randomization of cases to sections was executed by the computer program MÂS 7

The government decree allowed for some exceptions from the randomization procedure described above. These exceptions often included cases involving youth defendants and cases involving the least serious crimes (e.g., traffic offenses). Often, cases involving the most serious crimes (e.g., murder, rape) were also assigned outside of the MÅHS program to ensure that both the judge and prosecutor have enough experience for the case. In practice, these exceptions meant that the randomization of cases to court sections typically occurred within crime type and age group during our sample period. As discussed below, we therefore account for both defendant age and crime type when calculating our measure of judge stringency $]^{8}$

\section{Comparison to the Other Countries}

The criminal justice system in Sweden is broadly similar to many other developed countries, particularly other Nordic countries. In comparison, the United States is an outlier in most dimensions. This section briefly reviews the differences most relevant to our analysis.

Incarceration Rates: Appendix Figure A2 plots incarceration rates per 100,000 individuals in Sweden, the United States, and all remaining European and North American OECD countries. The incarceration rate in Sweden has been relatively stable over the last 35 years, increasing from 55 individuals per 100,000 in 1980 to 79 individuals per 100,000 in 2006, then falling back to 61 individuals per 100,000 in 2014. Incarceration rates in other OECD countries have followed a largely similar trend over time, albeit from a slightly higher base. In stark contrast, incarceration rates in the United States increased from 220 individuals per 100,000 in 1980 to 693 individuals per 100,000

\footnotetext{
${ }^{7}$ The exact procedure used to randomize cases to sections varied somewhat across the different courts in our sample. In smaller courts, cases were usually randomly assigned to sections directly. In larger courts, however, cases were usually randomly assigned first to departments, then to sections. In both scenarios, cases are effectively randomized to sections.

${ }^{8}$ Information on the case assignment process during our sample period is available in numerous publicly available court documents. We were able to independently confirm the details of the case assignment process during this time period through informal conversations with judges and court administrators and hand-collected district court work orders (Arbetsordningarna) documenting the assignment processes in each court.
} 
by $2014 \sqrt[9]{9}$

Sentence lengths are also considerably shorter in Sweden compared to the United States. Conditional on any incarceration, the median prison sentence in our sample is only 3.0 months, and more than $80 \%$ of sentences are shorter than one year. The actual time served is also much less than the recorded sentences, as nearly all prisoners receive probation after two-thirds of the sentence if there are no extraordinary circumstances. In contrast, the typical prison sentence is 6.8 months in Western Europe (Aebi, Tiago, and Burkhardt 2015) and 2.9 years in the United States (Pew Center 2011).

Prison and Post-Prison Supports: Similar to the other Nordic countries, the Swedish criminal justice system offers an extensive set of prison and post-prison supports meant to rehabilitate incarcerated individuals. Upon their incarceration, prisoners work with the prison staff to develop a personalized plan for their prison sentence. The prison staff use information on each prisoner's socioeconomic background, education, housing, family, drug addictions, and so on when developing the personalized incarceration plan. Swedish prisoners are also required to participate in some combination of work, education, treatment, vocational training, or parental skills training during their incarceration, and all Swedish prisons offer formal educational services and programs in self-management and selfcontrol. In addition, Swedish prisons offer prisoners extensive free medical services, with basic medical services provided by a full-time nursing staff, and more specialized services provided by visiting general practitioners and psychiatrists. Most prisons also provide accommodation where family members can stay free of charge for weekends with the prisoner without supervision.

Swedish prisons take a number of steps just prior to prisoners' release to ease readjustment to general society and reduce recidivism. For example, many prisoners are allowed to work (for about $\$ 1.50$ per hour), receive treatment or education, or participate in training away from prison during the day while remaining in residence at the prison. Some prisoners are even allowed to live at home and go back to regular work near the end of their incarceration spell. There are also programs that allow prisoners to receive treatment, normally for substance abuse, at their home rather than in prison during this time. Finally, some inmates are allowed to live in halfway homes, run by the

\footnotetext{
${ }^{9}$ There is a longstanding debate on reasons behind the low incarceration rate in the Nordic countries. This debate has only intensified after the closure of four Swedish prisons due to low occupancy in 2013. One potential reason for the low incarceration rate is that the Nordic countries tend to prioritize other forms of criminal sanctions (e.g., community service, supervision, probation and mandatory treatment) above incarceration. As will be discussed below, another possibility is the extensive post-prison supports provided by the Nordic countries (e.g., treatment programs for offenders with drug/alcohol or violence issues). The Swedish Supreme Court also reduced the length of prison sentences for serious drug offenses by more than a third in 2011, contributing to the falling incarceration rate observed in Appendix Figure A2
} 
Prison and Probation Service, towards the end of their prison sentence to help bridge the gap from incarceration to normal life.

Appendix Figure A3 plots the estimated costs of incarcerating an inmate for one year in a selected set of OECD countries. The annual cost per inmate in Sweden is over $\$ 140,000$, about the same as Norway but considerably higher than most other European countries. The high costs in Sweden are largely due to the extensive prison supports described above, as well as a relatively high ratio of guards to inmates. In contrast, costs per inmate are particularly low in the United States at about $\$ 35,000$ per year, in part due to the underfunding of prison supports and substantial overcrowding in many prisons (e.g., Davis et al. 2013, Department of Justice 2015).

The Swedish Welfare State: Like the other Nordic countries, Sweden has a much more generous social welfare system than most other developed countries. This social welfare system includes high-quality health care and education programs for children and generous public income security programs for adults. For example, health care is free for all children in Sweden, with nearly all children attending regular check-ups to monitor their development. Child care is also highly subsidized, with about $90 \%$ of costs are covered by the state for most families. In addition, there is a flat rate child allowance available to families and, from the age of six, every child has equal access to free education in their local area and universities free of charge. Families are also eligible for a means-tested social aid program that provides economic resources sufficient to keep them out of poverty as a last resort. All of these programs are considerably more generous than the equivalent programs in most European countries and the United States 10

Despite the large welfare state, however, there are no specific supports provided to the children of incarcerated parents in Sweden. There are no official efforts to even identify these children by school or government administrators, and little is known about the well-being of these children (e.g., Kriminalvården 2015). In this way, Sweden is broadly similar to most other developed countries, where there are few specific supports for the children of incarcerated parents.

\section{External Validity}

Given the considerable differences between the criminal justice and social welfare systems in Sweden and other developed countries, our results likely represent a lower bound on the consequences of parental incarceration. For example, it is likely that the free health care, the high-quality education

\footnotetext{
${ }^{10}$ See Johansson, Laun, and Palme (2014) for additional details on the Swedish social welfare system.
} 
programs, and the more generous government transfers in Sweden ameliorate some of the adverse consequences of parental incarceration. It is also likely that Sweden's criminal justice system, with comparatively short sentences, relatively family-friendly prisons, and an emphasis on rehabilitation, mitigates some of the negative effects of incarceration for both parents and their children. On the other hand, since incarceration is less common in Sweden than in many other countries, including the United States, it may be perceived as more stigmatizing.

Murray et al. (2007) find a much weaker correlation between parental incarceration and child delinquency in Sweden than in other European countries, supporting the hypothesis of weaker longterm effects of incarceration in Sweden than in other countries. Growing up in a poor neighborhood is also less harmful in Sweden than in the United States (Åslund et al. 2011) and, perhaps as a result, intergenerational mobility is also considerably higher in Sweden than in the United States (Björklund and Jäntti 1997). On the other hand, we find that incarceration has a very similar effect on an individual's own labor market outcomes in Sweden as in the United States (Mueller-Smith 2015), suggesting that the effects on children may be similar as well 11

\section{Data}

\section{A. Data Sources and Sample Construction}

Our empirical analysis uses several administrative datasets that we can link through unique personal identification numbers for each individual. The merged dataset covers all Swedish residents born between 1940 and 1985, along with their parents and children.

Information on criminal behavior and court cases comes from the conviction register provided by the Swedish National Council for Crime Prevention (see www.bra.se). The crime data include information on all convictions between 1973 and 2010. We observe the date of the crime, the date of conviction, the type of crime committed, the sentence imposed by the court, and unique identifiers for judges, defendants, and district courts. For children, crime outcomes are only available from age 15. We merge these data to information on family linkages contained in the multi-generation register created and maintained by Statistics Sweden (Statistics Sweden 2017).

\footnotetext{
${ }^{11}$ Our results may also differ from those in other countries if there are differences in what types of cases are at the margin of incarceration. Given the comparative leniency of the Swedish criminal justice system, it seems likely that parents at the margin of incarceration in Sweden are more negatively selected than parents at the margin of incarceration in other countries. However, it is not clear how the effects of parental incarceration will differ at these other margins and, as mentioned above, there are nearly identical effects of incarceration on an individual's own labor market outcomes in Sweden and the United States.
} 
The multi-generation register contains the personal identification numbers for all individuals born in Sweden starting in or after 1932 along with the personal identification numbers of each individual's parents and children. We then merge these datasets to the LISA register provided by Statistics Sweden (Statistics Sweden 2016). The LISA data contains rich longitudinal data that includes outcomes for every Swedish resident from 1990 to 2010. For each year, the data contain information on the entire families' earnings and transfers from the tax registers, and information on educational attainment after age 16 from the education register. We convert all nominal values in the LISA data to U.S. dollars using an exchange rate of eight Swedish Krona to one U.S. dollar.

We make three restrictions to our estimation sample. First, we restrict the sample to criminal cases occurring between January 1997 and December 2004. Prior to January 1997, criminal cases did not have to be randomly assigned to judges. After December 2004, the data handling system was changed and several courts abandoned the case assignment procedure that randomized cases to judges. Second, we restrict the sample to sections who handle at least 50 criminal cases (of either parents or non-parents) in a given year to reduce the noise in our judge stringency measure. Finally, we restrict the sample to families with children between the ages of 11 and 14 as of the trial date so that we observe each outcome for all children in our sample. The final estimation sample contains 45,425 cases from 604 sections and 55,324 children from 32,455 families. As discussed below, we calculate judge stringency using cases of both parents and non-parents in our sample range in order to reduce noise in the instrument. This larger sample contains 351,354 cases from the same 604 sections.

\section{B. Descriptive Statistics}

Table 1 reports summary statistics for our estimation sample. Panel A presents demographic characteristics for children in our estimation sample whose parents are and are not incarcerated following their trial. In our sample, $51.5 \%$ of children are male and over $90 \%$ are Swedish born, with a slightly higher proportion of native-born children among those with an incarcerated parent. The average age is just under 12.5 years old for both those with and without an incarcerated parent.

Panel B presents subsequent outcomes for children whose parents are and are not incarcerated. Consistent with the strong intergenerational correlations documented in prior work (e.g., Wildeman and Western 2010), children with an incarcerated parent have far worse outcomes than children without an incarcerated parent. In our sample, for example, $23.7 \%$ of children with an incarcerated parent are convicted of a crime between the ages of 15 and 17 compared to $19.0 \%$ of children 
without an incarcerated parent. Over half of these convictions involve property crime, about a quarter involve violent crime, and about 10\% involve drug crime. For female children, 3.0\% of children with an incarcerated parent have a pregnancy between the ages of 15 and 17 compared to $2.3 \%$ of children without an incarcerated parent. High school graduation is low for both groups, with only $38.7 \%$ of children with an incarcerated parent and $46.2 \%$ of children without an incarcerated parent receiving a diploma by age 19 .

In terms of labor market outcomes, employment rates at age 20 are relatively high at $69.7 \%$ for children with an incarcerated parent and $73.9 \%$ for children without an incarcerated parent. Formal sector earnings are low, however, at just over $\$ 8,000$ for both groups (including 0s). Welfare receipt at age 20 is also relatively high, at $38.6 \%$ or children with an incarcerated parent and $30.3 \%$ for children without an incarcerated parent. Taken together, these statistics indicate that children in our sample have largely left the education system by age 20, with relatively high rates of formal sector employment for such young individuals. However, the low earnings and high rates of welfare receipt among these youth suggest relatively weak connections to the formal sector.

Panel C presents demographic characteristics and baseline outcomes for the parent on trial. Over $89 \%$ of incarcerated parents and $78.7 \%$ of non-incarcerated parents are male. Just over $69 \%$ of both incarcerated and non-incarcerated parents are native born, with an average age of about 40 years old at the time of incarceration. Education levels are extremely low in our sample, with only $11.8 \%$ of incarcerated parents and $21.5 \%$ of non-incarcerated parents having at least a high school degree. Baseline outcomes are also extremely poor for parents in our sample, particularly for the incarcerated parents. Sixty-eight percent of incarcerated parents have a prior conviction, $38.6 \%$ were employed at baseline, and average baseline earnings were only $\$ 6,775$ (including 0s). For non-incarcerated parents, $38.3 \%$ have a prior conviction, $58.9 \%$ were employed at baseline, and average baseline earnings were $\$ 13,864$.

Finally, Panel D presents subsequent outcomes for the parent on trial. Over the next six years, $74.6 \%$ of incarcerated parents and $52.7 \%$ of non-incarcerated parents have a new criminal conviction. Employment rates are only $32.5 \%$ for incarcerated parents and $54.9 \%$ for non-incarcerated parents over the same time period, with welfare use at $51.0 \%$ for incarcerated parents and $33.9 \%$ for nonincarcerated parents. The proportion of parents living in a single-adult household is also relatively high, at $70.6 \%$ for incarcerated parents and $50.4 \%$ for non-incarcerated parents. 


\section{Research Design}

Overview: For individual $i$ with parent $p$ charged in case $c$ in year $t$, consider a model that relates outcomes such as teen crime to an indicator for whether the individual's parent was incarcerated during childhood, Prison $_{p c t}$ :

$$
Y_{i p c t}=\beta_{0}+\beta_{1} \text { Prison }_{p c t}+\beta_{2} \mathbf{X}_{i p c t}+\varepsilon_{i p c t}
$$

where $Y_{i p c t}$ is the outcome of interest for individual $i, \mathbf{X}_{i p c t}$ is a vector of case- and family-level controls, and $\varepsilon_{i p c t}$ is an error term. The key problem for inference is that OLS estimates of Equation (1) are likely to be biased due to unobserved factors which are correlated across generations. For example, criminal behavior could be correlated across generations due to unobservable variables common to the parent and child, such as living in a bad neighborhood or attending a low-quality school. The potential for this type of bias is suggested by the strong intergenerational links in outcomes such as education (e.g., Currie and Moretti 2003, Björklund, Lindahl, and Plug 2006, Holmlund, Lindahl, and Plug 2011, Lundborg, Nilsson, and Rooth 2014, Chetty et al. 2017) and earnings (e.g., Lee and Solon 2009, Chetty et al. 2014, Chetty et al. 2017).

To address this issue, we estimate the causal impact of parental incarceration using a leave-out measure of judge stringency as an instrument for the incarceration of a parent in childhood. In this specification, we interpret the reduced form impact of a parent being assigned to a more strict judge as the causal effect of the change in the probability of incarceration associated with judge assignment. This empirical design allows us to recover the local average treatment effect (LATE) of parental incarceration for cases where judges disagree on the appropriate sentence.

Instrumental Variable Calculation: Following Dahl et al. (2014) and Dobbie et al. (forthcoming), we construct our instrument using a residualized, leave-out measure of judge stringency that accounts for court-by-year, court-by-age, and court-by-crime-type fixed effects. Including exhaustive courtby-time, -age, and -crime-type effects effectively limits the comparison to defendants at risk of being assigned to the same set of judges. We can therefore interpret the within-cell variation in the instrument as variation in the propensity of a quasi-randomly assigned judge to incarcerate a defendant relative to the otherwise similar cases seen in the same court and year. The use of a residualized stringency measure, rather than a simple leave-out measure of judge stringency, allows us to construct our instrument using all defendants, not just those with children in the estimation 
sample. The larger sample means that our instrument is measured with considerably more precision, particularly in smaller courts where there are a relatively small number of cases involving parents each year. In unreported results, we find similar but less precise results when we calculate the instrument using only our estimation sample.

Formally, let the residual incarceration decision after removing the effect of court-by-time, -age, and -crime-type fixed effects be denoted by:

$$
\text { Prison }_{p c t}^{*}=\text { Prison }_{p c t}-\gamma \mathbf{X}_{c t}=Z_{c t j}+\varepsilon_{p c t}
$$

where $\mathbf{X}_{c t}$ includes the court-by-year, court-by-age, and court-by-crime-type fixed effects described above ${ }^{12}$ The residual incarceration decision, Prison $_{p c t}^{*}$, includes our measure of judge stringency $Z_{c t j}$, as well as idiosyncratic defendant- and case-level variation $\varepsilon_{p c t}$.

For each parent $p$, we use these residual incarceration decisions to calculate the leave-out incarceration rate of the assigned judge based on all other cases assigned in the same year:

$$
Z_{p t j}=\left(\frac{1}{n_{t j}-n_{p t j}}\right)\left(\sum_{k=0}^{n_{t j}}\left(\operatorname{Prison}_{p k t}^{*}\right)-\sum_{c=0}^{n_{p t j}}\left(\text { Prison }_{p c t}^{*}\right)\right)
$$

where $n_{t j}$ is the number of cases seen by judge $j$ in year $t$ and $n_{p t j}$ is the number of cases of parent $p$ seen by judge $j$ in year $t$. This leave-out measure is important for our analysis because regressing outcomes for parent $p$ on our judge stringency measure without leaving out the data from parent $p$ would introduce the same estimation errors on both the left- and right-hand side of the regression and produce biased estimates of the causal impact of being incarcerated. We remove the residualized incarceration decisions of all of an individual's cases seen by judge $j$ in each year, not just case $c$, to remove all such estimation errors. In our two-stage least squares results, we use this leave-out judge stringency measure, $Z_{p t j}$, as an instrumental variable for whether a parent is incarcerated ${ }^{13}$

We calculate our instrument across all defendants and cases (e.g., cases involving both male and female defendants), but allow the instrument to vary across years in order to capture the fact that judge tendencies tend to evolve over time. While we find that judge stringency is correlated

\footnotetext{
${ }^{12}$ We construct crime-type controls using detailed information on each charge. We aggregate these charge data into just over 500 separate charge types to flexibly control for crime type. Results are robust to more aggregate codings of the crime-type variable.

${ }^{13}$ Our leave-out mean measure is algebraically equivalent to a judge fixed effect estimated in a leave-out regression estimated in each year. The leave-out procedure is essentially a reduced-form version of jackknife IV, which is recommended when the number of instruments (the judge-by-year fixed effects) is likely to increase with sample size (Stock, Wright, and Yogo 2002, Kolesár et al. 2015).
} 
across the different years in our sample period, the correlation falls sharply with time (see Appendix Table A2). We also find that judge stringency calculated using cases in the same year is far more predictive of case decisions than judge stringency calculated in other years (see Appendix Table A3). In robustness checks, we present results using a number of alternative instruments to test the sensitivity of our results.

Judge Variation: Appendix Figure A4 plots the distribution of our leave-out judge stringency measure at the judge-by-year level. We observe just over 300 judges in each year of our data, with 604 judges observed over the course of the entire sample period. The median judge-by-year cell contains 127 cases, although only a subset of these cases include parents. The standard deviation of our leave-out measure is 0.051 , indicating that a one standard deviation increase in the judge stringency distribution is associated with a 5.1 percentage point increase in the probability of incarceration, an $18.1 \%$ change from the mean incarceration rate of $28.1 \%$.

Using this variation in judge stringency as an instrument for the incarceration of a parent, we identify the LATE of parental incarceration for children whose parents are at the margin of incarceration compared to children whose parents were convicted but not incarcerated. The conditions necessary to interpret these two-stage least squares estimates as the causal impact of parental incarceration are that: (1) judge assignment impacts parental incarceration, (2) judge assignment only impacts child outcomes through the probability of parental incarceration, and (3) there is a monotonic impact of judge assignment on parental incarceration. We now consider whether each of these conditions holds in our data.

First Stage: To examine the first stage relationship between judge stringency $Z_{c t j}$ and parental incarceration (Prison), we estimate the following equation for individual $i$ with parent $p$ who is charged in case $c$, assigned to judge $j$, at time $t$ using a linear probability model:

$$
\text { Prison }_{i p c t j}=\alpha_{0}+\alpha_{1} Z_{c t j}+\alpha_{2} \mathbf{X}_{i p c t}+\varepsilon_{i p c t}
$$

where the vector $\mathbf{X}_{i p c t}$ includes court-by-time fixed effects. As described previously, $Z_{c t j}$ are leaveout (jackknife) measures of judge stringency that are allowed to vary across years. We obtain similar results using a probit model, which is unsurprising given that the mean incarceration rate is 0.281 and far from zero or one. Robust standard errors are two-way clustered at the family and court section level throughout. 
Table 2 presents formal first stage results from Equation (4). Column 1 of Table 2 presents the mean incarceration rate in our estimation sample. Column 2 reports first stage results controlling only for court-by-year fixed effects. Column 3 adds the baseline case and family characteristics from Table 1 and indicators for any missing baseline characteristics. With all controls (column 3), we find that having a parent assigned to a judge that is 10 percentage points more likely to incarcerate increases the probability of parental incarceration by 5.49 percentage points.

Appendix Figure A4 provides a graphical representation of the same first stage relationship but with no parametric assumptions. We again find that our residualized judge instrument is highly predictive of whether a parent is incarcerated, with the probability of incarceration increasing monotonically, and approximately linearly, with our judge stringency measure. Consistent with past work (e.g., Mueller-Smith 2015, Bhuller et al. 2016), however, the probability of incarceration does not increase one-for-one with our measure of judge stringency, likely because of measurement error that attenuates the effect toward zero. For example, judge stringency may drift over the course of the year or case outcomes may be influenced by the lay jurors, reducing the accuracy of our leave-out stringency measure. Nevertheless, these results confirm that judge assignment is highly predictive of parental incarceration in our setting.

Instrument Validity: Two additional conditions must hold to interpret our two-stage least squares estimates as the LATE of parental incarceration: (1) an exclusion restriction where judge assignment only impacts child outcomes through the probability of parental incarceration and (2) a monotonicity restriction where the impact of judge assignment on the probability of incarceration is monotonic across parents.

Table 3 verifies that assignment of cases to judges is random after we condition on the fixed effects described above. The first column of Table 3 uses a linear probability model to test whether baseline case and family characteristics are predictive of parental incarceration. We control for court-by-year fixed effects and two-way cluster standard errors at the family and court section level. We find that defendants with native-born children are 8.6 percentage points more likely to be incarcerated, a $30.6 \%$ increase from the mean incarceration rate of $28.1 \%$. Fathers are also 17.5 percentage points more likely to be incarcerated than mothers, a $62.3 \%$ change from the mean incarceration rate. Defendants with lower levels of education and lower earnings are also at a higher risk of incarceration compared to more educated and higher earning defendants. Column 2 assesses whether these same observable characteristics are predictive of our judge stringency measure using 
an identical specification. We find that judges of differing tendencies are assigned very similar cases $($ joint $\mathrm{p}$-value $=0.401)$.

The exclusion restriction could also be violated if judge assignment impacts future outcomes through channels other than parental incarceration. If judge stringency impacts future outcomes through any other channels, then the resulting LATE would incorporate any additional impacts associated with judge assignment. The assumption that judges only systematically affect child outcomes through parental incarceration is fundamentally untestable, and our estimates should be interpreted with this potential caveat in mind. However, we argue that the exclusion restriction assumption is reasonable in our setting. Unlike judges in the United States who typically impose a combination of incarceration, probation, and fines (Mueller-Smith 2015), the Swedish penal code requires that judges only impose one type of punishment in the vast majority of situations ${ }^{14}$ We also find little relationship between our measure of judge stringency and sentence length conditional on any incarceration, and only $6 \%$ of defendants are found innocent in our sample, leaving relatively little scope through which the assigned judge could influence outcomes other than through the incarceration of a parent 15 While we cannot rule out every possible channel through which judge assignment could impact defendants and their children (e.g., speaking harshly at the sentencing hearing), we believe that such factors are unlikely to significantly bias our results. To the extent that the exclusion restriction is violated, our reduced form estimates can still be interpreted as the causal impact of having a parent assigned to a more or less stringent judge ${ }^{16}$

The second condition needed to interpret our estimates as the LATE of parental incarceration is that the impact of judge assignment on the probability of incarceration is monotonic across parents. In our setting, the monotonicity assumption requires that parents who are not incarcerated by a strict judge would also not be incarcerated by a more lenient judge, and that parents incarcerated by a lenient judge would also be incarcerated by a more strict judge. If the monotonicity assumption

\footnotetext{
${ }^{14}$ Swedish judges are only allowed to assign multiple punishments in a few, limited cases. For example, judges may sometimes impose both a fine and probation for certain low-level crimes. Consistent with these restrictions, there are virtually no defendants receiving multiple punishments in our sample. Results are identical if we drop these isolated cases or control for all of the imposed punishments.

${ }^{15}$ We find no meaningful relationship between our measure of judge stringency and sentence length conditional on incarceration, likely because judges are required to follow relatively strict sentencing length guidelines determined by the Supreme Court and the Prosecutor Authority. Bhuller et al. (2016) also find no meaningful relationship between judge stringency and sentence length conditional on incarceration in Norway, the setting most similar to our own, while Mueller-Smith (2015) finds a more significant relationship between judge assignment and sentence length in the United States, where judges may be less constrained when assigning prison sentences.

${ }^{16}$ As discussed above, other court actors such as the prosector and lay jurors are assigned through different processes than the judge. These institutional characteristics make it unlikely that judge assignment is correlated with the assignment of other criminal justice actors, who may independently affect the outcomes of defendants of their children.
} 
is violated, our two-stage least squares estimates would still be a weighted average of marginal treatment effects, but the weights would not sum to one (Angrist, Imbens, and Rubin 1996, Heckman and Vytlacil 2005). The monotonicity assumption is therefore necessary to interpret our IV estimates as a well-defined LATE. The bias away from this well-defined LATE is an increasing function of the number of individuals for whom the monotonicity assumption does not hold and the difference in the marginal treatment effects for those individuals for whom the monotonicity assumption does and does not hold. The amount of bias is also a decreasing function of the strength of the first stage relationship shown in Table 2 and Appendix Figure A4 (Angrist et al.1996).

An implication of the monotonicity assumption is that the first stage estimates should be nonnegative for all subsamples. In Appendix Table A4 results, we find that our residualized measure of judge stringency is consistently positive and sizable in all subsamples, in line with the monotonicity assumption. In robustness checks, we relax the monotonicity assumption by letting our leave-out measure of judge stringency differ across case and family characteristics.

\section{Results}

In this section, we examine the causal effects of parental incarceration on risky behaviors, educational attainment, and early-life labor market outcomes. We then discuss potential mechanisms for our results.

\section{A. Risky Behaviors}

Table 4 presents OLS, reduced form, and two-stage least squares estimates of the impact of parental incarceration on teen crime and pregnancy. Teen crime is measured using an indicator for having a criminal conviction between the ages of 15 and 17, a proxy for criminal behavior during this time period. Pregnancy is measured using an indicator for having a pregnancy in the national health records between the ages of 15 and 17 . The pregnancy results only include female children, while the crime results include both male and female children. Column 1 reports dependent variable means for children whose parents were incarcerated. Column 2 reports OLS estimates controlling for court-byyear effects and the baseline controls listed in Table1. Column 3 reports OLS estimates reweighted so that the proportion of compliers matches the share of the estimation sample ${ }^{17}$ Column 4 reports

\footnotetext{
${ }^{17}$ Following Bhuller et al. (2016) and Dobbie et al. (forthcoming), we split our estimation sample into eight mutually exclusive and collectively exhaustive subsamples based on prior criminal history and the predicted probability of incarceration. We then calculate the share of compliers in each subsample. The weights are calculated as the share of compliers relative to the share of the estimation sample in each subsample. See Online Appendix B for additional
} 
reduced form results of the impact of having a parent assigned to a more stringent judge using the leave-out measure of judge stringency described in Section III. Finally, column 5 reports two-stage least squares results where we instrument for parental incarceration using the leave-out measure of judge stringency. All regressions control for court-by-year fixed effects and the baseline controls listed in Table 1. Standard errors two-way clustered at the family and court section level are reported in parentheses.

Consistent with past work (e.g., Johnson 2009), OLS estimates show that individuals with an incarcerated parent are significantly more likely to have a criminal conviction in their teen years. For example, controlling for court-by-year effects and all baseline controls (column 2), we find that an individual with an incarcerated parent is 1.5 percentage points more likely to have a criminal conviction between the ages of 15 and 17, a $6.3 \%$ increase from the mean for these individuals. Convictions for property crime are 1.1 percentage points higher over the same age range, while violent crime convictions are 0.4 percentage points higher and drug crime convictions are only 0.3 percentage points higher. The OLS estimates suggest little to no relationship between parental incarceration and pregnancy between the ages of 15 and 17, with the point estimate suggesting a statistically insignificant 0.2 percentage point increase for female children. Reweighting our estimation sample to match the sample of compliers (column 3) only modestly changes the size of the OLS estimates, suggesting that any differences between the OLS and two-stage least squares estimates are not due to treatment effect heterogeneity, at least on observables.

The reduced form and two-stage least squares estimates in columns 4-5 improve upon our OLS estimates by exploiting plausibly exogenous variation in parental incarceration from the random assignment of cases to judges. We find that the assignment of a parent to a more stringent judge leads to economically and statistically significant increases in both teen crime and pregnancy (column 4). Under the stronger assumptions necessary to use judge stringency as an instrumental variable (column 5), we estimate that parental incarceration increases the probability of having a criminal conviction between the ages of 15 and 17 by 9.9 percentage points for children whose parents are on the margin of incarceration, a $41.7 \%$ increase from the mean. We find particularly large effects for property and violent crime convictions for these individuals, with smaller and statistically insignificant effects on drug crime convictions. We also find that parental incarceration increases the probability of teen pregnancy by 6.0 percentage points for marginal cases, a $200.0 \%$ increase from the mean. All of the reduced form and two-stage least squares results suggest economically and

details on these calculations. 
statistically significant effects of parental incarceration on children's early-life behavioral outcomes.

The fact that our IV estimates are systematically larger than the corresponding OLS estimates suggests that there are particularly large effects of parental incarceration for children whose parents are at the margin of incarceration. This finding further suggests that there are particularly small effects of parental incarceration for children whose parents are not at the margin of incarceration, perhaps because they are at such a low or high risk of teen crime and pregnancy that their decisions are not affected by the incarceration of a parent. Children whose parents are charged with relatively minor offenses may, for example, be at such a low risk of teen crime or pregnancy that they never participate in these types of risky behaviors, while children whose parents are charged with the most serious offenses may be at such a disadvantage that they will almost always be involved in these risky behaviors 18

\section{B. Human Capital and Labor Market Outcomes}

Table 5 presents estimates of the impact of parental incarceration on educational attainment and formal sector employment and earnings. Educational attainment is measured using indicators for high school graduation by age 19 and any school enrollment at age 20. Unfortunately, we cannot distinguish between high school and college enrollment in our data, meaning that the latter results include both types of schooling. We measure early-life labor market participation using an indicator for any positive earnings at age 20, total earnings at age 20, and an indicator for welfare receipt at age 20 .

The OLS estimates in Table 5 show that individuals with an incarcerated parent are only modestly less likely to graduate from high school by age 19, be enrolled in either high school or college at age 20, or be employed in the formal sector labor market at age 20 (columns 2-3). The two-stage least squares estimates for our education outcomes are broadly similar to the OLS estimates, but less precisely estimated. We find, for example, that parental incarceration decreases the probability of graduating from high school by age 19 by a statistically insignificant 1.3 percentage points for cases at the margin of incarceration, a 3.4\% decrease from the mean. The probability of being enrolled in any type of schooling at age 20 decreases by only a statistically insignificant 6.0 percentage points,

\footnotetext{
${ }^{18}$ There is little systematic relationship between the IV and OLS estimates in prior work using random-judge designs. Consistent with our findings, for example, Aizer and Doyle (2015) and Dobbie et al. (forthcoming) find IV estimates that are larger (in absolute value) than the corresponding OLS estimates for juvenile incarceration and pre-trial detention in the United States, respectively. In contrast, Mueller-Smith (2015) finds IV estimates that are approximately equal to the corresponding OLS estimates for adult incarceration in the United States, and Bhuller et al. (2016) find IV estimates that are smaller (in absolute value) than the corresponding OLS estimates for adult incarceration in Norway.
} 
a $15.0 \%$ decrease.

In contrast, our two-stage least squares estimates reveal economically large effects of parental incarceration on labor market participation. Parental incarceration significantly decreases the probability of paid employment at age 20 by 16.5 percentage points for children whose parents are on the margin of incarceration, a $23.7 \%$ decrease from the mean. Earnings at age 20 also decrease by $\$ 1,654$ for these marginal cases, a $20.2 \%$ change, while welfare receipt increases by 9.6 percentage points, a $24.9 \%$ change. Neither estimate is statistically significant, however, due to large standard errors.

To explore why we find a less precisely estimated impact of parental incarceration on the intensive margin of employment, Panel A of Appendix Figure A5 plots two-stage least squares estimates and corresponding $90 \%$ confidence intervals of the impact of parental incarceration on the probability of a child's earnings at age 20 falling above various thresholds. The impact of parental incarceration on child earnings is concentrated in the left tail of the earnings distribution, with little to no effect on the probability of earning above higher thresholds such as $\$ 20,000$ or $\$ 30,000$. These results suggest that parental incarceration primarily affects child earnings at the very low-end of the income distribution, with little discernible effect at other points of the distribution. One possible explanation for these results is that parental incarceration has a larger impact on children at the margin of any employment, with relatively little impact on children with higher potential earnings. Consistent with this explanation, we show below that the effects of parental incarceration are concentrated among children from the most disadvantaged families. We also find that employment at age 20 is a much stronger predictor of earnings at ages 25, 30, and 35 than earnings at age 20 (see Online Appendix C), perhaps because of the considerable dispersion in early-life earnings.

\section{Subsample Results}

Appendix Table A5 presents two-stage least squares results by child gender, child age, and the gender of the convicted parent. While we caution against a strong interpretation of these subsample results given concerns about multiple hypothesis testing, there is some evidence that the effects of parental incarceration are larger for both female children and younger children. For female children, for example, parental incarceration increases teen convictions by 14.7 percentage points (90.2\%) and decreases employment by 32.0 percentage points for cases at the margin of incarceration. In comparison, parental incarceration increases teen convictions by only 6.9 percentage points $(22.5 \%)$ and decreases employment by only a statistically insignificant 5.9 percentage points (8.8\%) for 
male children. Similarly, we find that parental incarceration decreases high school graduation by 39.8 percentage points $(103.4 \%)$ and employment by 70.1 percentage points $(101.2 \%)$ for children who were 11 to 12 years old when their parent was incarcerated, with smaller and statistically insignificant effects for children who were 13 to 14 years old at the time of incarceration 19 We also find larger point estimates for children with an incarcerated mother compared to children with an incarcerated father, but large standard errors mean that most of these differences are not statistically significant 20

\section{Robustness}

Appendix Table A6 explores the sensitivity of our main results to alternative samples and specifications. Column 1 broadens our estimation sample to district court sections that handle at least 25 criminal cases in a given year. Column 2 instead restricts the estimation sample to sections that handle at least 75 criminal cases in a given year. Column 3 restricts the sample to first time cases. Column 4 calculates judge stringency using a random $25 \%$ subset of the data and estimates the treatment effects in the opposing subset of data. Column 5 calculates judge stringency in two equal-sized and mutually exclusive sub-samples and estimates results by stacking the two subsamples. Results are generally similar to our preferred specification across these alternative specifications, although some of our estimates lose statistical significance. In particular, our point estimates on teen convictions and employment at age 20 are more sensitive to alternative specifications, although large standard errors mean that the results are not statistically different from our preferred specifications.

Appendix Table A7 presents a second set of robustness checks where the instrument is calculated separately by different mutually exclusive subsamples, thereby relaxing the monotonicity assumption. We include results using instruments calculated separately for male and female parents, parents living in one- and two-adult households at baseline, parents above and below the median age in our sample at baseline, native- and foreign-born parents, parents with less than or at least a high

\footnotetext{
${ }^{19}$ These subsample results are broadly consistent with prior work finding larger effects of early-life interventions (e.g., Anderson 2008, Gould, Lavy, and Paserman 2011, Hoynes, Schanzenbach, and Almond 2016, Grönqvist, Nilsson, and Robling 2017), peer effects (e.g., Kling, Liebman, and Katz 2007, Lavy, Silva, and Weinhardt 2012, Deming et al. 2014), and schooling (Hastings, Kane, and Staiger 2006, Jackson 2012, Deming et al. 2014), for female children, and larger effects of family income (e.g., Dahl and Lochner 2012, education (e.g., Levy and Duncan 2000, Jacob and Lefgren 2009), and neighborhood quality (e.g., Chetty, Hendren, and Katz 2016, Chetty and Hendren 2017) for younger children.

${ }^{20}$ There is an ongoing debate within the criminology literature on the relative effects of paternal versus maternal incarceration. While our results suggest that there are larger effects of maternal incarceration, they are by no means definitive proof on this issue. See Wildeman and Turney (2014) and Wildeman (forthcoming) for recent evidence on this issue.
} 
school education, nonemployed and employed parents at baseline, and parents with and without a prior offense at baseline. Importantly, these are the same parent- and case-level subsamples where we find most treatment effect heterogeneity. Results across these different specifications are again similar to our preferred specification, although there is considerably more noise when using smaller cells to calculate the leave-out judge stringency measure. None of the estimates suggest that our preferred estimates are invalid, suggesting that the potential bias from any monotonicity violations is likely to be small.

\section{Potential Mechanisms}

In this section, we explore two potential mechanisms that might explain our findings: (1) changes in family income and family structure and (2) the particular sensitivity of disadvantaged children to the shock of parental incarceration.

Family Income and Family Structure: One potential explanation for our results is that parental incarceration disrupts family relationships (e.g., Lopoo and Western 2005) and reduces future employment and earnings opportunities (e.g., Mueller-Smith 2015, Bäckman, Estrada, and Nilsson 2017), leading to the negative effects on children documented above. Consistent with this hypothesis, there is a large literature showing significant correlations between later-life outcomes and both family income and family structure (e.g., Brooks-Gunn and Duncan 1997), although the extent to which these associations are causal remains contested (e.g., Mayer 1997).

We begin by estimating the impact of incarceration on a parent's own outcomes in Table 6. We find little impact of incarceration on future crime for parents at the margin of incarceration, but a large negative impact of incarceration on parental employment and family structure ${ }^{21}$ Over the first six years following conviction, employment decreases by 15.7 percentage points for parents at the margin of incarceration, a $48.3 \%$ change, formal sector earnings decrease by $\$ 7,045$, a $104.3 \%$ change, and welfare use increases by 10.9 percentage points, a $21.4 \%$ change. The increase in welfare use only partially offsets the fall in labor market earnings, with income net of government transfers falling by a statistically insignificant $\$ 2,632$ following an incarceration spell (see Appendix Table

\footnotetext{
${ }^{21}$ In theory, incarceration may decrease future crime through deterrence, incapacitation, or rehabilitation effects, or increase future crime due to negative peer or stigmatization effects. These competing theoretical channels may explain the null result on future crime, particularly the emphasis on rehabilitation in the Swedish criminal justice system. Appendix Table A8 presents additional estimates by future crime type. Incarceration decreases future property crime by 15.6 percentage points, but increases future violent crime by 13.9 percentage points and future drug crime by 9.9 percentage points.
} 
A8). We also find that incarceration increases the probability that the convicted parent lives in a one-adult household by 19.5 percentage points, a $27.6 \%$ change. All of our results suggest substantial negative effects of incarceration on a parent's own outcomes and, as a result, the home environment for children in the full sample 22

To test whether the deterioration of parent outcomes can explain our results, we examine whether the child effects and the parent effects are concentrated in the same subsamples. If the child effects are driven by the parent effects, we would expect to see a positive correlation in the subsamples where these effects are concentrated. The failure to find such a correlation would therefore suggest that some other mechanism must be driving our results. To implement this test, Table 7 presents estimates for both children and parents separately by a summary index of family disadvantage based on the baseline education, employment, criminal history, and history of drug or alcohol abuse for both biological parents. We use family disadvantage to split our sample both the prior literature suggests considerable heterogeneity in the effects of other shocks by baseline disadvantage (e.g., Wilson 1996, Oreopoulos et al. 2008, Adda et al. 2011, Coelli 2011) and, just as importantly, family disadvantage is constant within a family, unlike baseline variables such as gender or nationality that can vary across family members ${ }^{23}$

Table 7 reveals a significant negative correlation between the effects on children's outcomes and the effects on a parent's own outcomes at the subsample level, suggesting that the effects of parental incarceration on children are unlikely to be driven by changes in family income or family structure. The negative effects of parental incarceration on children are driven almost entirely by children

\footnotetext{
${ }^{22}$ We provide a number of robustness checks for these results in the appendix. We find economically and statistically significant effects throughout the earnings distribution (see Appendix Figure A5. We also find similar results among the full sample of defendants, indicating that our results are not specific to parents (see Appendix Table A9), and nearly identical labor market results in both the first through third and fourth through sixth years after the initial conviction, indicating that our results are not driven by a mechanical incapacitation effect (see Appendix Table A10). Our results are broadly consistent with recent work showing large negative effects of incarceration on labor market outcomes in both Sweden (Bäckman et al. 2017) and the United States (Mueller-Smith 2015), but contrast sharply with recent work showing large positive effects of incarceration on labor market outcomes in Norway (Bhuller et al. 2016). The reason for these contrasting results is unclear. We find smaller but still negative results among all defendants, indicating that the difference is unlikely to be due to the difference in samples. We also find similar results in a sample of unemployed defendants where the effects are most positive in Norway. One possible explanation is the slightly stronger focus on rehabilitation in Norway, where, for example, $16 \%$ of those employed in prisons are working on workplace rehabilitation and education compared to only $9 \%$ in Sweden (Aebi, Tiago, and Burkhardt 2017 ).

${ }^{23}$ Formally, we construct our family disadvantage index in three steps. First, we standardize each individual measure in our index to have a mean of zero and a standard deviation of one, with the sign of each variable oriented so that worse outcomes have higher scores. We then take the average of each standardized z-score measure. Finally, we divide the sample at the median of the index. Baseline education is measured using an indicator for having less than a high school diploma. Baseline employment is measured using indicators for paid employment prior to the trial. Criminal history is measured using an indicator for having a prior conviction at any point in the last 20 years. Drug and alcohol abuse is measured using an indicator for whether the parent has either been convicted for a drugor alcohol-related crime or been hospitalized for a drug- or alcohol-related disease at any point in the last 20 years.
} 
from the most disadvantaged families, with no detectable effects of parental incarceration among children from advantaged families for any of our outcomes. In sharp contrast to the results for children, the negative effects of incarceration on a parent's own outcomes are concentrated among the most advantaged families. In other words, there is no overlap in the subsamples where we observe significant child effects and significant parent effects. The negative correlation between the effects on children's outcomes and the effects on a parent's own outcomes largely holds when we define family disadvantage using either just the convicted parent or just the non-convicted parent, with particularly stark results when defining disadvantage using just the convicted parent (see Appendix Table A11). We also find a negative correlation between the effects on children's outcomes and the effects on a parent's own outcomes for almost every one of the individual components of the disadvantage index, although some estimates become imprecise due to small sample sizes (see Appendix Tables A12 and A13.

These results suggest that the effects of incarceration on children's outcomes are concentrated among families where the effects on parents are small and imprecisely estimated, while the effects on parent's own outcomes are concentrated among families where the effects on children are similarly small and indistinguishable from zero. Thus, our results provide no support for the hypothesis that the effects of parental incarceration on children are driven by changes in parental earnings or family structure.

Fragile Families: A second possibility is that the negative effects of parental incarceration can be explained by the particular sensitivity of disadvantaged children to the trauma of having a parent sent to prison. Prior work suggests that disadvantaged children may be particularly harmed by shocks such as parental incarceration because they are more sensitive to the loss of a (relatively) positive role model (e.g., Wilson 1996), to the negative stigma effects of having an incarcerated parent (e.g., Hagan and Dinovitzer 1999), or to psychological trauma more generally (e.g., Harding 2003, Wodtke et al. 2016). There is also work showing that low-income children are particularly sensitive to parental job loss (Oreopoulos et al. 2008, Coelli 2011), parental death (Adda et al. 2011), and parental EITC transfers (Dahl and Lochner 2012).

One piece of evidence in support of this hypothesis comes from the Table 7 results discussed above, which show that the negative effects of parental incarceration on children are driven almost entirely by children from the most disadvantaged families. For these disadvantaged children, parental incarceration increases teen convictions by 18.4 percentage points $(71.0 \%)$, increases teen 
pregnancies by 8.0 percentage points $(222.2 \%)$, and decreases employment at age 20 by 27.9 percentage points $(41.8 \%)$. By comparison, there are no detectable effects of parental incarceration among children from advantaged families for any of our outcomes.

Further evidence comes from a more an examination of the most disadvantaged children in our data. For children whose non-convicted parent has a prior conviction, for example, parental incarceration increases teen convictions by 30.6 percentage points $(103.4 \%)$ and decreases employment at age 20 by 45.6 percentage points (71.7\%) (see Appendix Table A13). For children whose nonconvicted parent has a history of drug and alcohol abuse, teen convictions similarly increase by 39.6 percentage points (133.8\%) and employment at age 20 decreases by 54.4 percentage points $(83.4 \%)$ (see Appendix Table A13). We also find larger estimates for children where both parents are classified as highly disadvantaged, another group that is arguably among the most disadvantaged (see Appendix Table A14. While there is no conclusive evidence on this issue, all of our results suggest that disadvantaged children are particularly sensitive to the effects of parental incarceration 24

Other Mechanisms: There are several additional explanations for our results that we cannot examine with our current data. For example, it is possible that the harmful effects of parental incarceration can be explained by changes in neighborhood or school quality. Parental incarceration could also impact children through its effects on the mental health or emotional well-being of the remaining parent. Unfortunately, our data do not include information on these variables 25

Taken together, our results suggest that the negative effects of parental incarceration on children can be explained by the particular sensitivity of disadvantaged children to the shock of having a parent sent to prison. In contrast, we find limited support for the hypothesis that changes in family income or family structure negatively impact children. These results are broadly consistent with recent

\footnotetext{
${ }^{24}$ Though we hesitate to draw strong conclusions from Appendix Table A14 due to large standard errors, the results are consistent with the quality of the remaining parent being particularly important, perhaps because he or she becomes the primary caregiver after the incarceration of the convicted parent. The results in Appendix Table A14 also speak against the idea that our findings are due to the temporary removal of a (relatively) positive role model, as this would imply larger effects for children with relatively more advantaged convicted parents.

${ }^{25}$ Another explanation for our results is that parental incarceration increases the probability that a child is placed into foster care, which can directly impact both risky behavior and decrease employment (e.g., Doyle 2007, Doyle 2008). While our current data do not have information on foster care placements, we consider this explanation unlikely in our setting for two reasons. First, very few children are placed into foster care in Sweden, with only $0.2 \%$ of children under the age of 12 and only $0.5 \%$ of children between the ages of 13 and 17 spending one or more nights in foster care during our sample period (Socialstyrelsen 2013). Second, prior work suggests that there are much more modest negative effects of foster care placement in Sweden than in the United States, perhaps because of the stronger emphasis on placing foster children with families in Sweden (e.g., Vinnerljung et al. 2006, Lindquist and Santavirta 2014). On the other hand, there are slightly larger effects of foster care placement on crime for children between the ages of 11 and 14 in both Sweden (Lindquist and Santavirta 2014) and the United States (Doyle 2007), suggesting that we cannot completely rule out this explanation for our results.
} 
work showing that positive wealth shocks have little effect on children's medium-run outcomes in either the United States (Jacob et al. 2015) or Sweden (Cesarini et al. 2016). Our results also provide additional support for prior work arguing that the negative effects of parental incarceration come from both the initial shock of losing a parent to prison and the cycle of imprisonment and release that often follows, not the loss of family income or the rise in single-parent households per se (e.g., Wildeman 2010, Murray et al. 2012).

\section{Conclusion}

This paper estimates the causal impact of parental incarceration on teen crime and pregnancy, high school graduation, and early-life employment. We find that the incarceration of a parent in childhood significantly increases teen crime and pregnancy and significantly decreases early-life employment. Our estimate for educational attainment is smaller and statistically insignificant. The negative effects of parental incarceration on children can be explained by the particular sensitivity of disadvantaged children to having a parent sent to prison, rather than the increase in single-adult households or the loss of family income that often follow an incarceration spell.

Our findings suggest that the incarceration of parents with young children may significantly increase the intergenerational persistence of poverty and criminal behavior. While we are unable to directly measure the long-run impact of parental incarceration on children using our data, we consider a partial back-of-the-envelope calculation that accounts for the costs of future child crime, pregnancy, and welfare receipt, the benefits of future parental crime reduction due to incapacitation, the costs of future parental welfare receipt, and the direct economic impacts on both parents and their children. To calculate the implied effect of parental incarceration on children's lifetime earnings, we regress later-life earnings on indicators for teen crime, teen pregnancy, high school graduation, and employment at age 20 using information on older cohorts of Swedish children with an incarcerated parent. We then multiply each OLS coefficient from this regression with the corresponding two-stage least squares coefficient from Tables 4 and 5 . We repeat this procedure for earnings at age 25,30, and 35, assuming a constant treatment effect after age 35. Information on the social costs coming from future crime, pregnancy, and welfare receipt come from the existing literature. See Online Appendix C for a full description of this exercise.

Based on these calculations, we estimate that parental incarceration decreases each child's future lifetime earnings by $\$ 79,962$. This is equivalent to a loss of $\$ 36,471$ per child in present value at age 14 if we discount future earnings at a $3 \%$ interest rate. The social costs coming from the effects of 
parental incarceration on child crime, pregnancy, and welfare receipt add an additional $\$ 21,792$ to $\$ 27,193$ in present value to this amount. Taking into account the average number of children per family (2.767) and the effects of incarceration on an individual's own outcomes, we find that the social cost of incarcerating a parent is over $\$ 300,000$ per family, more than double the social cost of incarcerating a non-parent 26

There are three important limitations to our analysis. First, we are unable to estimate the deterrence effects of a more or less strict incarceration policy (e.g., Chalfin and McCrary 2017). Our analysis will therefore overstate the social costs of incarceration if the threat of incarceration decreases crime rates. Second, we are unable to directly measure the long-run impacts of parental incarceration on long-run outcomes, and must instead rely on the tentative calculations described above to estimate the long-term effects of parental incarceration. Finally, our instrumental variables results are only valid for children whose parents are on the margin of incarceration. It is plausible that the effects of parental incarceration are very different for children whose parents are either never incarcerated or always incarcerated by the judges in our sample. Given these concerns, we are unable to determine the full welfare consequences of parental incarceration using our research design.

\section{References}

[1] Adda, Jerome, Anders Björklund, and Helena Holmlund. 2011. "The Role of Mothers and Fathers in Providing Skills: Evidence from Parental Deaths." IZA Discussion Paper No. 5425.

[2] Aebi, Marcelo F., Mélanie M. Tiago, and Christine Burkhardt. 2015. "SPACE Prison Populations Survey 2014." Council of Europe Annual Penal Statistics.

[3] Aebi, Marcelo F., Mélanie M. Tiago, and Christine Burkhardt. 2017. "SPACE Prison Populations Survey 2015." Council of Europe Annual Penal Statistics.

[4] Aizer, Anna, and Joseph J. Doyle Jr. 2015. "Juvenile Incarceration, Human Capital, and Future Crime: Evidence from Randomly-Assigned Judges." Quarterly Journal of Economics, 130(2): 759-803.

\footnotetext{
${ }^{26}$ We caution that these social cost calculations are speculative for at least two reasons. First, the correlation between early-life outcomes and long-term earnings may either under or overstate the causal impact of parental incarceration on long-term outcomes. Second, many of our two-stage least squares estimates are imprecise and, as a result, the confidence interval surrounding our long-term cost calculation is large.
} 
[5] Anderson, D. Mark. 2014. "In School and Out of Trouble? The Minimum Dropout Age and Juvenile Crime." Review of Economics and Statistics, 96(2): 318-331.

[6] Anderson, Michael L. 2008. "Multiple Inference and Gender Differences in the Effects of Early Intervention: A Reevaluation of the Abecedarian, Perry Preschool, and Early Training Projects." Journal of the American Statistical Association, 103(484): 1481-1495.

[7] Angrist, Joshua, Guido Imbens, and Donald Rubin. 1996. "Identification of Causal Effects Using Instrumental Variables." Journal of the American Statistical Association, 91(434): 444-455.

[8] Anwar, Shamena, Patrick Bayer, and Randi Hjalmarsson. "Politics in the Courtroom: Political Ideology and Jury Decision Making." Forthcoming in Journal of the European Economic Association.

[9] Åslund, Olof, Per-Anders Edin, Peter Fredriksson, and Hans Grönqvist. 2011. "Peers, Neighborhoods, and Immigrant Student Achievement: Evidence from a Placement Policy." American Economic Journal: Applied Economics, 3(2): 67-95.

[10] Bäckman, Olof, Felipe Estrada, and Anders Nilsson. 2017. "Locked Up and Locked Out? The Impact of Imprisonment on Labour Market Attachment." The British Journal of Criminology.

[11] Bayer, Patrick, Randi Hjalmarsson, and David Pozen. 2009. "Building Criminal Capital Behind Bars: Peer Effects in Juvenile Corrections." Quarterly Journal of Economics, 124(1): 105147.

[12] Bhuller, Manudeep, Gordon B. Dahl, Katrine V. Løken, and Magne Mogstad. 2016. "Incarceration, Recidivism and Employment." NBER Working Paper No. 22648.

[13] Bhuller, Manudeep, Gordon B. Dahl, Katrine V. Løken, and Magne Mogstad. "Intergenerational Effects of Incarceration." Forthcoming in AEA Papers \& Proceedings.

[14] Billings, Stephen B., David J. Deming, and Jonah E. Rockoff. 2013. "School Segregation, Educational Attainment and Crime: Evidence from the End of Busing in Charlotte-Mecklenburg." Quarterly Journal of Economics, 129(1): 435-476.

[15] Billings, Stephen B. 2017. "Parental Arrest, Incarceration and the Outcomes of Their Children." Unpublished Working Paper.

[16] Björklund, Anders. 2006. "Does Family Policy Affect Fertility?" Journal of Population Economics, 19(1): 3-24. 
[17] Björklund, Anders, and Markus Jäntti. 1997. "Intergenerational Income Mobility in Sweden Compared to the United States." American Economic Review, 87(5): 1009-1018.

[18] Björklund, Anders, Mikael Lindahl, and Erik Plug. 2006. "The Origins of Intergenerational Associations: Lessons from Swedish Adoption Data." Quarterly Journal of Economics, 121(3): 999-1028.

[19] Breining, Sanni N., Joseph J. Doyle Jr, David N. Figlio, Krzysztof Karbownik, and Jeffrey Roth. 2017. "Birth Order and Delinquency: Evidence from Denmark and Florida." NBER Working Paper No. 23038.

[20] Brooks-Gunn, Jeanne, and Greg J. Duncan. 1997. "The Effects of Poverty on Children." The Future of Children, 7(2): 55-71.

[21] Cesarini, David, Erik Lindqvist, Robert Östling, and Björn Wallace. 2016. "Wealth, Health, and Child Development: Evidence from Administrative Data on Swedish Lottery Players." Quarterly Journal of Economics, 131(2): 687-738.

[22] Chalfin, Aaron, and Justin McCrary. 2017. "Criminal Deterrence: A Review of the Literature." Journal of Economic Literature, 55(1): 5-48.

[23] Chetty, Raj, John N. Friedman, Emmanuel Saez, Nicholas Turner, and Danny Yagan. 2017. "Mobility Report Cards: The Role of Colleges in Intergenerational Mobility." NBER Working Paper No. 23618.

[24] Chetty, Raj, and Nathaniel Hendren. 2017. "The Impacts of Neighborhoods on Intergenerational Mobility: Childhood Exposure Effects and County-Level Estimates." NBER Working Paper No. 23001.

[25] Chetty, Raj, Nathaniel Hendren, and Lawrence F. Katz. 2016. "The Effects of Exposure to Better Neighborhoods on Children: New Evidence from the Moving to Opportunity Experiment." American Economic Review, 106(4): 855-902.

[26] Chetty, Raj, Nathaniel Hendren, Patrick Kline, and Emmanuel Saez. 2014. "Where Is the Land of Opportunity? The Geography of Intergenerational Mobility in the United States." Quarterly Journal of Economics, 129(4): 1553-1623.

[27] Cho, Rosa M. 2009a. "The Impact of Maternal Imprisonment on Children's Probability of Grade Retention: Results from Chicago Public Schools." Journal of Urban Economics, 65(1): 11-23. 
[28] Cho, Rosa M. 2009b. "The Impact of Maternal Incarceration on Children's Educational Achievement: Results from Chicago Public Schools." Journal of Human Resources, 44(3): 772-797.

[29] Coelli, Michael B. 2011. "Parental Job Loss and the Education Enrollment of Youth." Labour Economics, 18(1): 25-35.

[30] Cook, Philip J., and Songman Kang. 2016. "Birthdays, Schooling, and Crime: RegressionDiscontinuity Analysis of School Performance, Delinquency, Dropout, and Crime Initiation." American Economic Journal: Applied Economics, 8(1): 33-57.

[31] Currie, Janet, and Enrico Moretti. 2003. "Mother's Education and the Intergenerational Transmission of Human Capital: Evidence from College Openings." Quarterly Journal of Economics, 118(4): 1495-1532.

[32] Dahl, Gordon B., and Lance Lochner. 2012. "The Impact of Family Income on Child Achievement: Evidence from the Earned Income Tax Credit." American Economic Review, 102(5): 1927-1956.

[33] Dahl, Gordon B., Andreas Ravndal Kostøl, and Magne Mogstad. 2014. "Family Welfare Cultures." Quarterly Journal of Economics, 129(4): 1711-1752.

[34] Damm, Anna P., and Christian Dustmann. 2014. "Does Growing Up in a High Crime Neighborhood Affect Youth Criminal Behavior?" American Economic Review, 104(6): 1806-1832.

[35] Davis, Lois M., Robert Bozick, Jennifer L. Steele, Jessica Saunders, and Jeremy N.V. Miles. 2013. "Evaluating the Effectiveness of Correctional Education: A Meta-analysis of Programs that Provide Education to Incarcerated Adults." Rand Corporation.

[36] Deming, David J. 2011. "Better Schools, Less Crime?" Quarterly Journal of Economics, 126(4): 2063-2115.

[37] Deming, David J., Justine S. Hastings, Thomas J. Kane, and Douglas O. Staiger. 2014. "School Choice, School Quality, and Postsecondary Attainment." American Economic Review, 104(3): 991-1013.

[38] Department of Justice. 2015. "FY 2016 Performance Budget."

[39] Dobbie, Will, and Roland Fryer. 2015. "The Medium-Term Impacts of High-Achieving Charter Schools." Journal of Political Economy, 123(5): 985-1037.

[40] Dobbie, Will, Jacob Goldin, and Crystal Yang. "The Effects of Pre-Trial Detention on Conviction, Future Crime, and Employment: Evidence from Randomly Assigned Judges." Forth- 
coming in American Economic Review.

[41] Doyle, Joseph J. 2007. "Child Protection and Child Outcomes: Measuring the Effects of Foster Care." American Economic Review, 97(5): 1583-1610.

[42] Doyle, Joseph J. 2008. "Child Protection and Adult Crime: Using Investigator Assignment to Estimate Causal Effects of Foster Care." Journal of Political Economy, 116(4): 746-770.

[43] Foster, Holly, and John Hagan. 2007. "Incarceration and Intergenerational Social Exclusion." Social Problems, 54(4): 399-433.

[44] Gould, Eric D., Victor Lavy, and M. Daniele Paserman. 2011. "Sixty Years After the Magic Carpet Ride: The Long-Run Effect of the Early Childhood Environment on Social and Economic Outcomes." Review of Economic Studies, 78(3): 938-973.

[45] Grönqvist, Hans, J. Peter Nilsson, and Per-Olof Robling. 2017. "Early Lead Exposure and Outcomes in Adulthood." Unpublished Working Paper.

[46] Hagan, John, and Ronit Dinovitzer. 1999. "Collateral Consequences of Imprisonment for Children, Communities, and Prisoners." Crime and Justice, 26: 121-162.

[47] Harding, David J. 2003. "Counterfactual Models of Neighborhood Effects: The Effect of Neighborhood Poverty on Dropping Out and Teenage Pregnancy." American Journal of Sociology, 109(3): 676-719.

[48] Hastings, Justine S., Thomas J. Kane, and Douglas O. Staiger. 2006. "Gender and Performance: Evidence from School Assignment by Randomized Lottery." American Economic Review, 96(2): $232-236$.

[49] Havnes, Tarjei, and Magne Mogstad. 2015. "Is Universal Child Care Leveling the Playing Field?" Journal of Public Economics, 127: 100-114.

[50] Heckman, James J., and Edward Vytlacil. 2005. "Structural Equations, Treatment Effects, and Econometric Policy Evaluation." Econometrica, 73(3): 669-738.

[51] Hjalmarsson, Randi, Helena Holmlund, and Matthew J. Lindquist. 2015. "The Effect of Education on Criminal Convictions and Incarceration: Causal Evidence from Micro-data." Economic Journal, 125(587): 1290-1326.

[52] Hjalmarsson, Randi, and Matthew J. Lindquist. 2011. "The Origins of Intergenerational Associations in Crime: Lessons from Swedish Adoption Data." Labour Economics, 20: 68-81. 
[53] Hjalmarsson, Randi, and Matthew J. Lindquist. 2012. "Like Godfather, Like Son: Exploring the Intergenerational Nature of Crime." Journal of Human Resources, 47(2): 550-582.

[54] Holmlund, Helena, Mikael Lindahl, and Erik Plug. 2011. "The Causal Effect of Parents' Schooling on Children's Schooling: A Comparison of Estimation Methods." Journal of Economic Literature, 49(3): 615-651.

[55] Hoynes, Hilary, Diane W. Schanzenbach, and Douglas Almond. 2016. "Long-Run Impacts of Childhood Access to the Safety Net." American Economic Review, 106(4): 903-934.

[56] Jackson, C. Kirabo. 2012. "Single-Sex Schools, Student Achievement, and Course Selection: Evidence from Rule-Based Student Assignments in Trinidad and Tobago." Journal of Public Economics, 96(1): 173-187.

[57] Jacob, Brian A., Max Kapustin, and Jens Ludwig. 2015. "The Impact of Housing Assistance on Child Outcomes: Evidence from a Randomized Housing Lottery." Quarterly Journal of Economics, 130(1): 465-506.

[58] Jacob, Brian A., and Lars Lefgren. 2009. "The Effect of Grade Retention on High School Completion." American Economic Journal: Applied Economics, 1(3): 33-58.

[59] Johansson, Per, Lisa Laun, and Mårten Palme. 2014. "Pathways to Retirement and the Role of Financial Incentives in Sweden.” NBER Working Paper No. 20123.

[60] Johnson, Rucker C. 2009. "Ever-Increasing Levels of Parental Incarceration and the Consequences for Children." In Do Prisons Make Us Safer? The Benefits and Costs of the Prison Boom, eds. Steven Raphael and Michael Stoll, Russell Sage Foundation Press.

[61] Kling, Jeffrey R. 2006. "Incarceration Length, Employment, and Earnings." American Economic Review, 96(3): 863-876.

[62] Kling, Jeffrey R., Jeffrey B. Liebman, and Lawrence F. Katz. 2007. "Experimental Analysis of Neighborhood Effects." Econometrica, 75(1): 83-119.

[63] Kling, Jeffrey R., Jens Ludwig, and Lawrence F. Katz. 2005. "Neighborhood Effects on Crime for Female and Male Youth: Evidence from a Randomized Housing Voucher Experiment." Quarterly Journal of Economics, 120(1): 87-130.

[64] Kolesár, Michal, Raj Chetty, John Friedman, Edward Glaeser, and Guido Imbens. 2015. "Identification and Inference with Many Invalid Instruments." Journal of Business and Economic Statistics, 33(4): 474-484. 
[65] Kriminalvården. 2015. "Hedersrelaterat våld och förtryck: Forskning och utvärdering inom Kriminalvården." Norrköping: Kriminalvården.

[66] Lavy, Victor, Olmo Silva, and Felix Weinhardt. 2012. "The Good, the Bad, and the Average: Evidence on Ability Peer Effects in Schools." Journal of Labor Economics, 30(2): 367-414.

[67] Lee, Chul-In, and Gary Solon. 2009. "Trends in Intergenerational Income Mobility." Review of Economics and Statistics, 91(4): 766-772.

[68] Levy, Dan M., and Greg Duncan. 2000. "Using Sibling Samples to Assess the Effect of Childhood Family Income on Completed Schooling." Northwestern University/University of Chicago Joint Center for Poverty Research Working Paper No. 168.

[69] Lindquist, Matthew, and Torsten Santavirta. 2014. "Does Placing Children in Foster Care Increase their Adult Criminality?" Labour Economics, 31: 72-83.

[70] Lochner, Lance, and Enrico Moretti. 2004. "The Effect of Education on Crime: Evidence from Prison Inmates, Arrests, and Self-Reports." American Economic Review, 94(1): 155-189.

[71] Lopoo, Leonard M., and Bruce Western. 2005. "Incarceration and the Formation and Stability of Marital Unions." Journal of Marriage and Family, 67(3): 721-734.

[72] Lundborg, Petter, Anton Nilsson, and Dan-Olof Rooth. 2014. "Parental Education and Offspring Outcomes: Evidence from the Swedish Compulsory Schooling Reform." American Economic Journal: Applied Economics, 6(1): 253-278.

[73] Mayer, Susan E. 1997. What Money Can't Buy: Family Income and Children's Life Chances. Cambridge, MA: Harvard University Press.

[74] Meghir, Costas, Mårten Palme, and Marieke Schnabel. 2012. "The Effect of Education Policy on Crime: An Intergenerational Perspective." NBER Working Paper No. 18145.

[75] Mueller-Smith, Michael. 2015. "The Criminal and Labor Market Impacts of Incarceration." Unpublished Working Paper.

[76] Murphey, David, and P. Mae Cooper. 2015. "Parents Behind Bars: What Happens to Their Children?" https://www.childtrends.org/publications/ parents-behind-bars-what-happens-to-their-children/

[77] Murray, Joseph, and David P. Farrington. 2005. "Parental Imprisonment: Effects on Boys' Antisocial Behaviour and Delinquency Through the Life-Course." Journal of Child Psychology and Psychiatry, 46(12): 1269-1278. 
[78] Murray, Joseph, David P. Farrington, and Ivana Sekol. 2012. "Children's Antisocial Behavior, Mental Health, Drug Use, and Educational Performance After Parental Incarceration: A Systematic Review and Meta-analysis." Psychological Bulletin, 138(2): 175-210.

[79] Murray, Joseph, Carl-Gunnar Janson, and David P. Farrington. 2007. "Crime in Adult Offspring of Prisoners: A Cross-National Comparison of Two Longitudinal Samples." Criminal Justice and Behavior, 34(1): 133-149.

[80] Murray, Joseph, Rolf Loeber, and Dustin Pardini. 2012. "Parental Involvement in the Criminal Justice System and the Development of Youth Theft Marijuana Use, Depression and Poor Academic Performance." Criminology, 50(1): 255-302.

[81] Oreopoulos, Philip, Marianne Page, and Ann Huff Stevens. 2008. "The Intergenerational Effects of Worker Displacement." Journal of Labor Economics, 26(3): 455-483.

[82] Pew Center. 2011. "State of Recidivism: The Revolving Door of America's Prisons." Washington, DC: Pew Charitable Trusts.

[83] Sciandra, Matthew, Lisa Sanbonmatsu, Greg J. Duncan, Lisa A. Gennetian, Lawrence F. Katz, Ronald C. Kessler, Jeffrey R. Kling, and Jens Ludwig. 2013. "Long-term Effects of the Moving to Opportunity Residential Mobility Experiment on Crime and Delinquency." Journal of Experimental Criminology, 9(4): 451-489.

[84] Socialstyrelsen. 2013. "Barnoch ungainsatser år 2012: Vissa insatser enligt Socialtjänstlagen (SoL) och Lagen med Särskilda Bestämmelser för vård av Unga (LvU)."

[85] Stock, James, Jonathan H. Wright, and Motohiro Yogo. 2002. "A Survey of Weak Instruments and Weak Identification in Generalized Method of Moments." Journal of Business and Economic Statistics, 20(4): 518-529.

[86] Vinnerljung, Bo, Knut Sundell, Cecilia Andrée Löfholm and Eva Humlesjö. 2006. "Former Stockholm Child Protection Cases as Young Adults: Do Outcomes Differ Between Those That Received Services and Those That Did Not?" Children and Youth Services Review, 28(1): 59-77.

[87] Wildeman, Christopher. 2010. "Paternal Incarceration and Children's Physically Aggressive Behaviors: Evidence from the Fragile Families and Child Wellbeing Study." Social Forces, 89(1): 285-309.

[88] Wildeman, Christopher. "Parental Incarceration and Child Health in the United States: A 
Systematic Review." Forthcoming in Epidemiologic Reviews.

[89] Wildeman, Christopher, and Lars H. Andersen. 2015. "Cumulative Risks of Paternal and Maternal Incarceration in Denmark and the United States." Demographic Research, 32(57): 1567-1580.

[90] Wildeman, Christopher, and Signe Hald Andersen. 2016. "Paternal Incarceration and Children's Risk of Being Charged by Early Adulthood: Evidence from a Danish Policy Shock." Criminology, 55(1): 32-85.

[91] Wildeman, Christopher, Signe Hald Andersen, Hedwig Lee and Kristian Bernt Karlson. 2014. "Parental Incarceration and Child Mortality in Denmark." American Journal of Public Health, 104(3): 428-433.

[92] Wildeman, Christopher, and Kristin Turney. 2015. "Positive, Negative, or Null? The Effects of Maternal Incarceration on Children's Behavioral Problems." Demography, 51(3): 10411068.

[93] Wildeman, Christopher, and Bruce Western. 2010. "Incarceration in Fragile Families." The Future of Children, 20(2): 157-177.

[94] Wilson, William J. 1996. When Work Disappears: The World of the New Urban Poor. New York: Vintage Books.

[95] Wodtke, Geoffrey T., Felix Elwert, and David J. Harding. 2016. "Neighborhood Effect Heterogeneity by Family Income and Developmental Period." American Journal of Sociology, 121(4): 1168-1222. 
Table 1: Descriptive Statistics

\begin{tabular}{|c|c|c|}
\hline & $\begin{array}{c}\text { Parent } \\
\text { Incarcerated }\end{array}$ & $\begin{array}{l}\text { Parent Not } \\
\text { Incarcerated }\end{array}$ \\
\hline Panel A: Child Characteristics & $(1)$ & $(2)$ \\
\hline Male & 0.516 & 0.514 \\
\hline Native born & 0.932 & 0.902 \\
\hline Age at trial & 12.455 & 12.451 \\
\hline Birth order & 1.913 & 1.971 \\
\hline \multicolumn{3}{|l|}{ Panel B: Child Outcomes } \\
\hline Criminal conviction at ages $15-17$ & 0.237 & 0.190 \\
\hline Property conviction at ages $15-17$ & 0.128 & 0.098 \\
\hline Violent conviction at ages $15-17$ & 0.058 & 0.044 \\
\hline Drug conviction at ages $15-17$ & 0.024 & 0.016 \\
\hline Pregnancy at ages $15-17$ if female & 0.030 & 0.023 \\
\hline High school graduate at age 19 & 0.387 & 0.462 \\
\hline School enrollment at age 20 & 0.401 & 0.429 \\
\hline Employment at age 20 & 0.697 & 0.739 \\
\hline Earnings $(\$ 1,000 \mathrm{~s})$ at age 20 & 8.168 & 8.855 \\
\hline Welfare use at age 20 & 0.386 & 0.303 \\
\hline \multicolumn{3}{|c|}{ Panel C: Parent Characteristics and Baseline Outcomes } \\
\hline Male & 0.898 & 0.787 \\
\hline Native born & 0.695 & 0.690 \\
\hline Age at trial & 39.919 & 40.739 \\
\hline Number of children & 2.767 & 2.874 \\
\hline Below high school degree & 0.882 & 0.785 \\
\hline High school degree or above & 0.118 & 0.215 \\
\hline Criminal conviction in 3 years before crime & 0.680 & 0.383 \\
\hline Employment in 3 years before crime & 0.386 & 0.589 \\
\hline Earnings $(\$ 1,000 \mathrm{~s})$ in 3 years before crime & 6.775 & 13.864 \\
\hline \multicolumn{3}{|l|}{ Panel D: Parent Outcomes } \\
\hline Criminal conviction in 6 years after trial & 0.746 & 0.527 \\
\hline Employment in 6 years after trial & 0.325 & 0.549 \\
\hline Earnings $(\$ 1,000 \mathrm{~s})$ in 6 years after trial & 6.752 & 16.039 \\
\hline Welfare use in 6 years after trial & 0.510 & 0.339 \\
\hline Single-adult household in 6 years after trial & 0.706 & 0.504 \\
\hline Observations & 15,536 & 39,788 \\
\hline
\end{tabular}

Note: This table reports descriptive statistics for children with parents involved in a criminal trial between 1997 and 2004. Both samples are restricted to court sections with at least 50 cases each year and children aged 11-14 at the time of the trial. Crime outcomes for children are measured over ages 15-17. Baseline outcomes for the charged parents are measured over the three years before the trial date. Subsequent parent outcomes are measured using the average over the six years following the trial date for the charged parent. Nominal values are deflated to 2015 and represented in U.S. dollars using the exchange rate SEK $/ \$=8$. Single-adult household is an indicator for the charged parent filing as an individual tax unit. 
Table 2: First Stage Results

\begin{tabular}{lcccc}
\hline & \multicolumn{2}{c}{ Sample } & & \\
& Mean & & \multicolumn{2}{c}{ Any Incarceration } \\
\cline { 2 - 3 } \cline { 5 - 5 } Judge stringency & $(1)$ & & $(2)$ & $(3)$ \\
\cline { 2 - 3 } & 0.281 & & $0.581^{* * *}$ & $0.549^{* * *}$ \\
& $(0.449)$ & & $(0.068)$ & $(0.063)$ \\
\hline Court x Year FE & - & & Yes & Yes \\
Baseline Controls & - & & No & Yes \\
Observations & 55,324 & & 55,324 & 55,324 \\
\hline
\end{tabular}

Note: This table reports first stage results. The regressions are estimated on the sample as described in the notes to Table 1. Judge stringency is estimated using data from other cases assigned to a section in the same year following the procedure described in Section III. Column 1 reports the mean and standard deviation of the dependent variable. Column 2 reports results controlling for court-by-year fixed effects. Column 3 adds the controls listed in Table 1. Standard errors are two-way clustered at the parent (32,455 cells) and section ( 604 cells) levels. $* * *=$ significant at 1 percent level, ${ }^{* *}=$ significant at 5 percent level, ${ }^{*}=$ significant at 10 percent level. 
Table 3: Test of Randomization

\begin{tabular}{|c|c|c|}
\hline & $\begin{array}{c}\text { Parent } \\
\text { Incarcerated } \\
(1)\end{array}$ & $\begin{array}{c}\text { Judge } \\
\text { Stringency } \\
(2)\end{array}$ \\
\hline Child is male & $\begin{array}{c}0.00185 \\
(0.00422)\end{array}$ & $\begin{array}{c}0.00020 \\
(0.00037)\end{array}$ \\
\hline Child is native born & $\begin{array}{l}0.08595^{* * *} \\
(0.00990)\end{array}$ & $\begin{array}{r}0.00188^{*} \\
(0.00114)\end{array}$ \\
\hline Child age at trial & $\begin{array}{l}0.00546^{* * *} \\
(0.00150)\end{array}$ & $\begin{array}{c}0.00006 \\
(0.00018)\end{array}$ \\
\hline Child is a second child & $\begin{array}{c}0.00548 \\
(0.00420)\end{array}$ & $\begin{array}{r}-0.00027 \\
(0.00044)\end{array}$ \\
\hline Child is a third child & $\begin{array}{c}0.01291^{*} \\
(0.00661)\end{array}$ & $\begin{array}{r}-0.00100 \\
(0.00063)\end{array}$ \\
\hline Child is a forth or higher child & $\begin{array}{r}0.01503^{*} \\
(0.00908)\end{array}$ & $\begin{array}{r}-0.00035 \\
(0.00084)\end{array}$ \\
\hline Number of children in family & $\begin{array}{c}-0.01051^{* * *} \\
(0.00239)\end{array}$ & $\begin{array}{c}0.00007 \\
(0.00021)\end{array}$ \\
\hline Parent is male & $\begin{array}{l}0.17497^{* * *} \\
(0.00727)\end{array}$ & $\begin{array}{r}0.00133^{*} \\
(0.00073)\end{array}$ \\
\hline Parent is native born & $\begin{array}{r}-0.00613 \\
(0.00616)\end{array}$ & $\begin{array}{c}0.00033 \\
(0.00071)\end{array}$ \\
\hline Parent age at trial & $\begin{array}{c}-0.00264^{* * *} \\
(0.00045)\end{array}$ & $\begin{array}{r}-0.00005 \\
(0.00005)\end{array}$ \\
\hline Parent has high school diploma & $\begin{array}{c}-0.02657^{* * *} \\
(0.00822)\end{array}$ & $\begin{array}{c}0.00017 \\
(0.00105)\end{array}$ \\
\hline Parent has at least some college & $\begin{array}{c}-0.03678^{* * *} \\
(0.00782)\end{array}$ & $\begin{array}{r}-0.00037 \\
(0.00102)\end{array}$ \\
\hline Parent missing education data & $\begin{array}{c}-0.01927 \\
(0.01581)\end{array}$ & $\begin{array}{r}-0.00178 \\
(0.00150)\end{array}$ \\
\hline Parent employment in 3 years before crime & $\begin{array}{c}-0.11077^{* * *} \\
(0.00848)\end{array}$ & $\begin{array}{r}-0.00063 \\
(0.00079)\end{array}$ \\
\hline Parent earnings $(\$ 1,000 \mathrm{~s})$ in 3 years before crime & $\begin{array}{c}-0.00093^{* * *} \\
(0.00018)\end{array}$ & $\begin{array}{r}-0.00002 \\
(0.00002)\end{array}$ \\
\hline Parent welfare use in 3 years before crime & $\begin{array}{l}0.05025^{* * *} \\
(0.00752)\end{array}$ & $\begin{array}{r}-0.00062 \\
(0.00089)\end{array}$ \\
\hline Parent conviction in 3 years before crime & $\begin{array}{l}0.15615^{* * *} \\
(0.00579)\end{array}$ & $\begin{array}{c}0.00000 \\
(0.00058)\end{array}$ \\
\hline Parent missing baseline data & $\begin{array}{c}0.04387 \\
(0.02808)\end{array}$ & $\begin{array}{c}0.00216 \\
(0.00272)\end{array}$ \\
\hline Joint F-Test & {$[0.00000]$} & {$[0.40140]$} \\
\hline Observations & 55,324 & 55,324 \\
\hline
\end{tabular}

Note: This table reports reduced form results testing the random assignment of cases to sections. The regressions are estimated on the sample as described in the notes to Table 1. Column 1 reports estimates from an OLS regression of parental incarceration on the variables listed and randomization strata fixed effects. Column 2 reports estimates from an OLS regression of judge stringency on the variables listed and court-by-year fixed effects. Both specifications also include indicators for missing information. The p-value reported at the bottom of columns 1-2 is for a F-test of the joint significance of the variables listed in the rows. Standard errors are two-way clustered at the parent $(32,455$ cells) and section $\left(604\right.$ cells) levels. ${ }^{* * *}=$ significant at 1 percent level, ${ }^{* *}=$ significant at 5 percent level, ${ }^{*}=$ significant at 10 percent level. 
Table 4: Parental Incarceration and Risky Behavior

\begin{tabular}{|c|c|c|c|c|c|}
\hline & $\begin{array}{c}\text { Incarcerated } \\
\text { Mean }\end{array}$ & OLS & $\begin{array}{l}\text { OLS w/ } \\
\text { Weights }\end{array}$ & $\begin{array}{l}\text { Reduced } \\
\text { Form }\end{array}$ & 2SLS \\
\hline Panel A: Teen crime & (1) & $(2)$ & $(3)$ & $(4)$ & $(5)$ \\
\hline Any conviction at ages $15-17$ & $\begin{array}{c}0.237 \\
(0.425)\end{array}$ & $\begin{array}{l}0.015^{* * *} \\
(0.005)\end{array}$ & $\begin{array}{l}0.018^{* * *} \\
(0.007)\end{array}$ & $\begin{array}{l}0.055^{* *} \\
(0.028)\end{array}$ & $\begin{array}{c}0.099^{*} \\
(0.052)\end{array}$ \\
\hline Property conviction at ages $15-17$ & $\begin{array}{c}0.128 \\
(0.334)\end{array}$ & $\begin{array}{l}0.011^{* * *} \\
(0.004)\end{array}$ & $\begin{array}{l}0.016^{* *} \\
(0.007)\end{array}$ & $\begin{array}{l}0.044^{* *} \\
(0.022)\end{array}$ & $\begin{array}{c}0.079^{*} \\
(0.041)\end{array}$ \\
\hline Violent conviction at ages $15-17$ & $\begin{array}{c}0.058 \\
(0.234)\end{array}$ & $\begin{array}{c}0.004 \\
(0.003)\end{array}$ & $\begin{array}{c}0.005 \\
(0.005)\end{array}$ & $\begin{array}{l}0.043^{* * *} \\
(0.016)\end{array}$ & $\begin{array}{l}0.078^{* *} \\
(0.032)\end{array}$ \\
\hline Drug conviction at ages $15-17$ & $\begin{array}{c}0.024 \\
(0.154)\end{array}$ & $\begin{array}{r}0.003^{*} \\
(0.002)\end{array}$ & $\begin{array}{c}0.003 \\
(0.002)\end{array}$ & $\begin{array}{c}0.010 \\
(0.011)\end{array}$ & $\begin{array}{c}0.018 \\
(0.019)\end{array}$ \\
\hline \multicolumn{6}{|l|}{ Panel B: Teen pregnancy } \\
\hline Pregnancy at ages $15-17$ if female & $\begin{array}{c}0.030 \\
(0.171) \\
\end{array}$ & $\begin{array}{c}0.002 \\
(0.003) \\
\end{array}$ & $\begin{array}{c}0.000 \\
(0.004) \\
\end{array}$ & $\begin{array}{c}0.032^{* *} \\
(0.015) \\
\end{array}$ & $\begin{array}{l}0.060^{* *} \\
(0.030)\end{array}$ \\
\hline Court x Year FE & - & Yes & Yes & Yes & Yes \\
\hline Baseline Controls & - & Yes & Yes & Yes & Yes \\
\hline Observations & 15,536 & 55,324 & 55,324 & 55,324 & 55,324 \\
\hline
\end{tabular}

Note: This table reports OLS, reduced form, and two-stage least squares estimates of the impact of parent incarceration on child crime outcomes. The regressions are estimated on the sample as described in the notes to Table 1. Column 1 reports dependent variable means for children whose parents were incarcerated. Column 2 reports OLS estimates of parental incarceration. Column 3 reports OLS estimates of parental incarceration using weights proportional to the fraction of compliers in a given prior conviction by risk quartile cell. Column 4 reports reduced form estimates of a judge stringency measure that is estimated using data from other cases assigned to a court section in a given year. Column 5 reports two-stage least squares estimates that instrument for parental incarceration using judge stringency. All regressions control for court-by-year fixed effects and the baseline controls described in Section III. Standard errors are two-way clustered at the parent $\left(32,455\right.$ cells) and section ( 604 cells) levels. ${ }^{* * *}=$ significant at 1 percent level, ${ }^{* *}=$ significant at 5 percent level, ${ }^{*}=$ significant at 10 percent level. 
Table 5: Parental Incarceration and Human Capital and Labor Market Outcomes

\begin{tabular}{|c|c|c|c|c|c|}
\hline \multirow{3}{*}{$\begin{array}{l}\text { Panel A: Educational attainment } \\
\text { High school graduate at age } 19\end{array}$} & $\begin{array}{l}\text { Incarcerated } \\
\text { Mean }\end{array}$ & OLS & $\begin{array}{l}\text { OLS w/ } \\
\text { Weights }\end{array}$ & $\begin{array}{l}\text { Reduced } \\
\text { Form }\end{array}$ & 2SLS \\
\hline & (1) & $(2)$ & $(3)$ & (4) & (5) \\
\hline & $\begin{array}{c}0.387 \\
(0.487)\end{array}$ & $\begin{array}{l}-0.018^{* * *} \\
(0.007)\end{array}$ & $\begin{array}{c}-0.017^{* *} \\
(0.008)\end{array}$ & $\begin{array}{c}-0.006 \\
(0.044)\end{array}$ & $\begin{array}{r}-0.013 \\
(0.087)\end{array}$ \\
\hline High school or college at age 20 & $\begin{array}{c}0.401 \\
(0.490)\end{array}$ & $\begin{array}{l}-0.017^{* *} \\
(0.007)\end{array}$ & $\begin{array}{r}-0.017^{*} \\
(0.009)\end{array}$ & $\begin{array}{c}-0.027 \\
(0.047)\end{array}$ & $\begin{array}{r}-0.060 \\
(0.107)\end{array}$ \\
\hline \multicolumn{6}{|l|}{ Panel B: Labor market outcomes } \\
\hline Employment at age 20 & $\begin{array}{c}0.697 \\
(0.460)\end{array}$ & $\begin{array}{r}-0.011^{*} \\
(0.007)\end{array}$ & $\begin{array}{r}-0.013 \\
(0.009)\end{array}$ & $\begin{array}{r}-0.074^{*} \\
(0.043)\end{array}$ & $\begin{array}{r}-0.165^{*} \\
(0.096)\end{array}$ \\
\hline Earnings $(\$ 1,000 \mathrm{~s})$ at age 20 & $\begin{array}{c}8.168 \\
(10.044)\end{array}$ & $\begin{array}{r}-0.083 \\
(0.147)\end{array}$ & $\begin{array}{r}-0.264 \\
(0.170)\end{array}$ & $\begin{array}{r}-0.739 \\
(0.920)\end{array}$ & $\begin{array}{c}-1.654 \\
(2.070)\end{array}$ \\
\hline Welfare use at age 20 & $\begin{array}{c}0.386 \\
(0.487)\end{array}$ & $\begin{array}{l}0.020^{* * *} \\
(0.007)\end{array}$ & $\begin{array}{l}0.028^{* * *} \\
(0.009)\end{array}$ & $\begin{array}{c}0.043 \\
(0.050)\end{array}$ & $\begin{array}{c}0.096 \\
(0.117) \\
\end{array}$ \\
\hline Court x Year FE & - & Yes & Yes & Yes & Yes \\
\hline Baseline Controls & - & Yes & Yes & Yes & Yes \\
\hline Observations & 15,536 & 55,324 & 55,324 & 55,324 & 55,324 \\
\hline
\end{tabular}

Note: This table reports OLS, reduced form, and two-stage least squares estimates of the impact of parent incarceration on child crime outcomes. The regressions are estimated on the sample as described in the notes to Table 1. Column 1 reports dependent variable means for children whose parents were incarcerated. Column 2 reports OLS estimates of parental incarceration. Column 3 reports OLS estimates of parental incarceration using weights proportional to the fraction of compliers in a given prior conviction by risk quartile cell. Column 4 reports reduced form estimates of a judge stringency measure that is estimated using data from other cases assigned to a court section in a given year. Column 5 reports two-stage least squares estimates that instrument for parental incarceration using judge stringency. All regressions control for court-by-year fixed effects and the baseline controls described in Section III. Standard errors are two-way clustered at the parent $\left(32,455\right.$ cells) and section ( 604 cells) levels. ${ }^{* * *}=$ significant at 1 percent level, ${ }^{* *}=$ significant at 5 percent level, ${ }^{*}=$ significant at 10 percent level. 
Table 6: Parental Incarceration and Parent Outcomes

\begin{tabular}{|c|c|c|c|c|c|}
\hline \multirow{3}{*}{$\begin{array}{l}\text { Panel A: Future crime } \\
\text { Conviction in years } 1-6\end{array}$} & $\begin{array}{c}\text { Incarcerated } \\
\text { Mean }\end{array}$ & OLS & $\begin{array}{l}\text { OLS w/ } \\
\text { Weights } \\
\end{array}$ & $\begin{array}{l}\text { Reduced } \\
\text { Form }\end{array}$ & 2SLS \\
\hline & $(1)$ & $(2)$ & $(3)$ & $(4)$ & $(5)$ \\
\hline & $\begin{array}{c}0.746 \\
(0.435)\end{array}$ & $\begin{array}{l}0.058^{* * *} \\
(0.006)\end{array}$ & $\begin{array}{l}0.068^{* * *} \\
(0.008)\end{array}$ & $\begin{array}{l}-0.036 \\
(0.051)\end{array}$ & $\begin{array}{r}-0.066 \\
(0.092)\end{array}$ \\
\hline \multicolumn{6}{|l|}{ Panel B: Labor market outcomes } \\
\hline Employment in years 1-6 & $\begin{array}{c}0.325 \\
(0.381)\end{array}$ & $\begin{array}{l}-0.074^{* * *} \\
(0.004)\end{array}$ & $\begin{array}{l}-0.071^{* * *} \\
(0.007)\end{array}$ & $\begin{array}{l}-0.086^{* * *} \\
(0.031)\end{array}$ & $\begin{array}{l}-0.157^{* * *} \\
(0.057)\end{array}$ \\
\hline Earnings $(\$ 1,000 \mathrm{~s})$ in years 1-6 & $\begin{array}{c}6.752 \\
(13.349)\end{array}$ & $\begin{array}{l}-2.568^{* * *} \\
(0.178)\end{array}$ & $\begin{array}{l}-2.542^{* * *} \\
(0.360)\end{array}$ & $\begin{array}{c}-3.867^{* *} \\
(1.560)\end{array}$ & $\begin{array}{c}-7.045^{* *} \\
(2.938)\end{array}$ \\
\hline Welfare use in years $1-6$ & $\begin{array}{l}0.510 \\
(0.386)\end{array}$ & $\begin{array}{l}0.063^{* * *} \\
(0.005)\end{array}$ & $\begin{array}{l}0.061^{* * *} \\
(0.007)\end{array}$ & $\begin{array}{l}0.060^{* *} \\
(0.028)\end{array}$ & $\begin{array}{l}0.109^{* *} \\
(0.051)\end{array}$ \\
\hline \multicolumn{6}{|l|}{ Panel C: Family structure } \\
\hline Single-adult household in years $1-6$ & $\begin{array}{c}0.706 \\
(0.376)\end{array}$ & $\begin{array}{l}0.091^{* * *} \\
(0.005)\end{array}$ & $\begin{array}{l}0.101^{* * *} \\
(0.008)\end{array}$ & $\begin{array}{l}0.107^{* *} \\
(0.044)\end{array}$ & $\begin{array}{l}0.195^{* *} \\
(0.079)\end{array}$ \\
\hline Court x Year FE & - & Yes & Yes & Yes & Yes \\
\hline Baseline Controls & - & Yes & Yes & Yes & Yes \\
\hline Observations & 15,536 & 55,324 & 55,324 & 55,324 & 55,324 \\
\hline
\end{tabular}

Note: This table reports OLS, reduced form, and two-stage least squares estimates of the impact of parent incarceration on the parent's own outcomes. The regressions are estimated on the sample as described in the notes to Table 1. Column 1 reports dependent variable means for parents who were incarcerated. Column 2 reports OLS estimates of parental incarceration. Column 3 reports OLS estimates of parental incarceration using weights proportional to the fraction of compliers in a given prior conviction by risk quartile cell. Column 4 reports reduced form estimates of a judge stringency measure that is estimated using data from other cases assigned to a court section in a given year. Column 5 reports two-stage least squares estimates that instrument for parental incarceration using judge stringency. All regressions are run at the child level and control for court-by-year fixed effects and the baseline controls described in Section III. Standard errors are two-way clustered at the parent $\left(32,455\right.$ cells) and section $\left(604\right.$ cells) levels. ${ }^{* * *}=$ significant at 1 percent level, ${ }^{* *}=$ significant at 5 percent level, ${ }^{*}=$ significant at 10 percent level. 
Table 7: Results by Family Disadvantage

\begin{tabular}{|c|c|c|}
\hline & $\begin{array}{c}\text { High } \\
\text { Disadv. }\end{array}$ & $\begin{array}{c}\text { Low } \\
\text { Disadv. }\end{array}$ \\
\hline \multirow{3}{*}{$\begin{array}{l}\text { Panel A: Child Results } \\
\quad \text { Conviction at ages 15-17 }\end{array}$} & $(1)$ & $(2)$ \\
\hline & $\begin{array}{c}0.184^{* *} \\
(0.073)\end{array}$ & $\begin{array}{c}-0.043 \\
(0.082)\end{array}$ \\
\hline & {$[0.259]$} & {$[0.145]$} \\
\hline \multirow[t]{2}{*}{ Pregnancy at ages $15-17$} & $\begin{array}{c}0.080^{*} \\
(0.046)\end{array}$ & $\begin{array}{c}0.022 \\
(0.041)\end{array}$ \\
\hline & {$[0.036]$} & {$[0.013]$} \\
\hline \multirow[t]{2}{*}{ High school grad. at age 19} & $\begin{array}{r}-0.062 \\
(0.113)\end{array}$ & $\begin{array}{c}0.037 \\
(0.188)\end{array}$ \\
\hline & {$[0.330]$} & {$[0.558]$} \\
\hline \multirow[t]{2}{*}{ Employment at age 20} & $\begin{array}{c}-0.279^{* *} \\
(0.128)\end{array}$ & $\begin{array}{c}0.004 \\
(0.149)\end{array}$ \\
\hline & {$[0.667]$} & {$[0.791]$} \\
\hline \multicolumn{3}{|l|}{ Panel B: Parent Results } \\
\hline \multirow[t]{2}{*}{ Conviction in years 1-6 } & $\begin{array}{r}-0.070 \\
(0.112)\end{array}$ & $\begin{array}{c}-0.100 \\
(0.140)\end{array}$ \\
\hline & {$[0.757]$} & {$[0.410]$} \\
\hline \multirow[t]{2}{*}{ Employment in years 1-6 } & $\begin{array}{r}-0.082 \\
(0.069)\end{array}$ & $\begin{array}{c}-0.245^{\text {*** }} \\
(0.085)\end{array}$ \\
\hline & {$[0.298]$} & {$[0.682]$} \\
\hline \multirow[t]{2}{*}{ Welfare use in years $1-6$} & $\begin{array}{c}0.038 \\
(0.070)\end{array}$ & $\begin{array}{l}0.196^{* * *} \\
(0.069)\end{array}$ \\
\hline & {$[0.535]$} & {$[0.232]$} \\
\hline \multirow[t]{3}{*}{ Single-adult HH in years 1-6 } & -0.027 & $0.458^{* * *}$ \\
\hline & $(0.090)$ & $(0.114)$ \\
\hline & {$[0.667]$} & {$[0.449]$} \\
\hline Court x Year FE & Yes & Yes \\
\hline Baseline Controls & Yes & Yes \\
\hline Observations & 28,363 & 26,961 \\
\hline
\end{tabular}

Note: This table reports two-stage least squares results by family disadvantage. We measure family disadvantage using an index of standardized baseline parental education, parental employment, parental criminal history, and history of parental drug and alcohol abuse for both biological parents. High and low disadvantage are defined using the median of the standardized index. Dependent variable means for the incarcerated group are in brackets. See the notes for Tables 46 for details on the specification and variables. $* * *=$ significant at 1 percent level, ${ }^{* *}=$ significant at 5 percent level, ${ }^{*}=$ significant at 10 percent level. 


\section{Appendix A: Additional Results}

Appendix Table A1: District Courts in the Estimation Sample

\begin{tabular}{|c|c|c|c|}
\hline $\begin{array}{l}\text { District } \\
\text { Court }\end{array}$ & $\begin{array}{l}\text { Number of } \\
\text { Sections }\end{array}$ & $\begin{array}{l}\text { Total } \\
\text { Cases }\end{array}$ & $\begin{array}{c}\text { Sample } \\
\text { Cases }\end{array}$ \\
\hline (1) & $(2)$ & (3) & (4) \\
\hline Allingsås & 5 & 4056 & 669 \\
\hline Ängelholm & 4 & 1263 & 149 \\
\hline Ångermanland & 6 & 1460 & 189 \\
\hline Arvika & 3 & 1617 & 250 \\
\hline Blekinge & 6 & 2319 & 362 \\
\hline Boden & 2 & 459 & 33 \\
\hline Bollnäs & 3 & 2301 & 1252 \\
\hline Borås & 9 & 7265 & 1252 \\
\hline Eksjö & 5 & 2368 & 421 \\
\hline Enköping & 3 & 1956 & 328 \\
\hline Eskilstuna & 7 & 6823 & 1094 \\
\hline Eslöv & 3 & 1180 & 187 \\
\hline Falköping & 2 & 499 & 62 \\
\hline Falu & 8 & 5524 & 853 \\
\hline Gävle & 7 & 4071 & 640 \\
\hline Gällivare & 4 & 1297 & 113 \\
\hline Göteborg & 22 & 26871 & 4257 \\
\hline Gotland & 3 & 1781 & 167 \\
\hline Hallsberg & 2 & 553 & 35 \\
\hline Halmstad & 9 & 5175 & 757 \\
\hline Handen & 9 & 6140 & 916 \\
\hline Haparanda & 3 & 1482 & 209 \\
\hline Hässleholm & 3 & 2070 & 358 \\
\hline Härnösand & 3 & 935 & 129 \\
\hline Hedemora & 3 & 811 & 134 \\
\hline Helsingborg & 20 & 10537 & 1688 \\
\hline Huddinge & 24 & 10946 & 1530 \\
\hline Hudiksvall & 2 & 2068 & 268 \\
\hline Jakobsberg & 4 & 903 & 63 \\
\hline Jönkoping & 7 & 4802 & 875 \\
\hline Kalmar & 6 & 4895 & 750 \\
\hline Karlshamn & 2 & 553 & 74 \\
\hline Karlskoga & 2 & 1493 & 258 \\
\hline Karlskrona & 3 & 857 & 105 \\
\hline Karlstad & 7 & 5302 & 831 \\
\hline Katrineholm & 3 & 1968 & 311 \\
\hline Klippan & 3 & 580 & 109 \\
\hline Köping & 3 & 651 & 59 \\
\hline Kristianstad & 7 & 4342 & 633 \\
\hline Kristinehamn & 2 & 1482 & 247 \\
\hline Landskrona & 4 & 1117 & 175 \\
\hline Leksand & 2 & 282 & 18 \\
\hline Lidköping & 4 & 3482 & 614 \\
\hline Lindesberg & 2 & 1550 & 300 \\
\hline Linköping & 13 & 9072 & 1424 \\
\hline Ljungby & 3 & 1737 & 305 \\
\hline
\end{tabular}




\begin{tabular}{|c|c|c|c|}
\hline $\begin{array}{c}\text { District } \\
\text { Court }\end{array}$ & $\begin{array}{l}\text { Number of } \\
\text { Sections }\end{array}$ & $\begin{array}{l}\text { Total } \\
\text { Cases }\end{array}$ & $\begin{array}{c}\text { Sample } \\
\text { Cases }\end{array}$ \\
\hline (1) & $(2)$ & $(3)$ & $(4)$ \\
\hline Ludvika & 2 & 443 & 29 \\
\hline Luleå & 7 & 3649 & 484 \\
\hline Lund & 20 & 7407 & 1099 \\
\hline Lycksele & 3 & 971 & 83 \\
\hline Malmö & 15 & 20243 & 3134 \\
\hline Mariestad & 3 & 1798 & 228 \\
\hline Mjölby & 2 & 734 & 76 \\
\hline Mölndal & 8 & 4210 & 640 \\
\hline Mora & 3 & 1569 & 218 \\
\hline Motala & 2 & 502 & 34 \\
\hline Nacka & 6 & 3863 & 541 \\
\hline Norrköping & 19 & 9290 & 1465 \\
\hline Norrtälje & 3 & 1672 & 259 \\
\hline Nyköping & 4 & 4120 & 633 \\
\hline Örebro & 12 & 8379 & 1091 \\
\hline Örnskoldsvik & 2 & 675 & 69 \\
\hline Oskarshamn & 3 & 1880 & 300 \\
\hline Östersund & 6 & 4141 & 631 \\
\hline Piteå & 3 & 683 & 84 \\
\hline Ronneby & 2 & 374 & 26 \\
\hline Sala & 3 & 762 & 95 \\
\hline Sölvesborg & 2 & 321 & 41 \\
\hline Sandviken & 2 & 1336 & 161 \\
\hline Simrishamn & 2 & 341 & 30 \\
\hline Skellefteå & 4 & 1972 & 256 \\
\hline Skövde & 4 & 2707 & 446 \\
\hline Södertälje & 6 & 5628 & 864 \\
\hline Södra Roslag & 11 & 4246 & 477 \\
\hline Sollentuna & 15 & 7092 & 941 \\
\hline Solna & 9 & 5035 & 710 \\
\hline Stenungsund & 4 & 2184 & 358 \\
\hline Stockholm & 45 & 46580 & 6089 \\
\hline Strömstad & 2 & 875 & 117 \\
\hline Sundsvall & 7 & 6043 & 830 \\
\hline Sunne & 2 & 1201 & 174 \\
\hline Tierp & 3 & 1422 & 194 \\
\hline Trelleborg & 6 & 2579 & 414 \\
\hline Trollhättan & 3 & 2623 & 442 \\
\hline Uddevalla & 5 & 3150 & 540 \\
\hline Umeå & 7 & 4757 & 643 \\
\hline Uppsala & 23 & 8710 & 1196 \\
\hline Vänersborg & 6 & 3049 & 543 \\
\hline Varberg & 9 & 5252 & 852 \\
\hline Värnamo & 3 & 1984 & 370 \\
\hline Västerås & 8 & 3468 & 476 \\
\hline Västervik & 3 & 1743 & 282 \\
\hline Västmanland & 16 & 5651 & 948 \\
\hline Växjo & 6 & 4672 & 706 \\
\hline Ystad & 6 & 2222 & 427 \\
\hline
\end{tabular}

Note: This table provides additional details on the district courts in our estimation sample. Column 2 reports the number of sections in each district court. Column 3 reports the total number of cases that are used to calculate the judge stringency measure. Column 4 reports the number of cases that are in our estimation sample. 
Appendix Table A2: Pair-Wise Correlation of Judge Stringency Over Time

\begin{tabular}{lccccc}
\hline & $\begin{array}{c}\text { Stringency } \\
\text { in t-2 }\end{array}$ & $\begin{array}{c}\text { Stringency } \\
\text { in t-1 }\end{array}$ & $\begin{array}{c}\text { Stringency } \\
\text { in t }\end{array}$ & $\begin{array}{c}\text { Stringency } \\
\text { in t }+1\end{array}$ & $\begin{array}{c}\text { Stringency } \\
\text { in }+2\end{array}$ \\
\cline { 2 - 5 } (1) Stringency in t-2 & $(1)$ & $(2)$ & $(3)$ & $(4)$ & $(5)$ \\
(2) Stringency in t-1 & 0.327 & 1.000 & & & \\
(3) Stringency in t & 0.276 & 0.398 & 1.000 & & \\
(4) Stringency in t +1 & 0.236 & 0.264 & 0.375 & 1.000 & \\
(5) Stringency in t +2 & 0.215 & 0.262 & 0.262 & 0.331 & 1.000 \\
\hline
\end{tabular}

Note: This table reports pairwise correlations between judge stringency measures over time. The correlations are estimated on the sample as described in the notes to Table 1. Judge stringency is estimated using data from other cases assigned to a court section in a given year. 
Appendix Table A3: Additional First Stage Results

\begin{tabular}{|c|c|c|c|c|c|c|}
\hline \multirow{4}{*}{ Stringency in t } & \multicolumn{6}{|c|}{ Any Incarceration } \\
\hline & (1) & $(2)$ & $(3)$ & $(4)$ & $(5)$ & (6) \\
\hline & $0.549^{* * *}$ & $0.502^{* * *}$ & $0.421^{* * *}$ & $0.439^{* * *}$ & $0.513^{* * *}$ & $0.312^{* * *}$ \\
\hline & $(0.063)$ & $(0.059)$ & $(0.053)$ & $(0.057)$ & $(0.061)$ & $(0.052)$ \\
\hline Stringency in t-2 & & $0.234^{* * *}$ & & & & $0.113^{*}$ \\
\hline & & $(0.065)$ & & & & $(0.065)$ \\
\hline Stringency in t-1 & & & $0.388^{* * *}$ & & & $0.325^{* * *}$ \\
\hline & & & $(0.058)$ & & & $(0.060)$ \\
\hline Stringency in $t+1$ & & & & $0.398^{* * *}$ & & $0.328^{* * *}$ \\
\hline & & & & $(0.060)$ & & $(0.060)$ \\
\hline Stringency in $t+2$ & & & & & $0.262^{* * *}$ & $0.131^{* *}$ \\
\hline & & & & & $(0.062)$ & $(0.063)$ \\
\hline Court x Time FE & Yes & Yes & Yes & Yes & Yes & Yes \\
\hline Baseline Controls & Yes & Yes & Yes & Yes & Yes & Yes \\
\hline Observations & 55,324 & 55,324 & 55,324 & 55,324 & 55,324 & 55,324 \\
\hline
\end{tabular}

Note: This table reports OLS estimates of parental incarceration on residualized judge leniency measures calculated in each year. See the notes for Table 2 for additional details. $* * *=$ significant at 1 percent level, $* *=$ significant at 5 percent level, $*=$ significant at 10 percent level. 
Appendix Table A4: First Stage Results in Different Samples

\begin{tabular}{|c|c|c|c|}
\hline \multirow{4}{*}{$\begin{array}{l}\text { Sample Restriction } \\
\text { Full sample }\end{array}$} & \multirow{2}{*}{$\begin{array}{c}\text { Sample } \\
\text { Mean }\end{array}$} & \multicolumn{2}{|c|}{ Any Incarceration } \\
\hline & & $(2)$ & $(3)$ \\
\hline & 0.281 & $0.581^{* * *}$ & $0.549^{* * *}$ \\
\hline & $(0.449)$ & $(0.068)$ & $(0.063)$ \\
\hline \multirow[t]{2}{*}{ Male parents } & 0.308 & $0.643^{* * *}$ & $0.619^{* * *}$ \\
\hline & $(0.462)$ & $(0.078)$ & $(0.071)$ \\
\hline \multirow{2}{*}{ Female parents } & 0.157 & $0.291^{* * *}$ & $0.279^{* * *}$ \\
\hline & $(0.363)$ & $(0.070)$ & $(0.068)$ \\
\hline \multirow{2}{*}{ Parents younger than 41} & 0.301 & $0.564^{* * *}$ & $0.518^{* * *}$ \\
\hline & $(0.459)$ & $(0.078)$ & $(0.069)$ \\
\hline \multirow[t]{2}{*}{ Parents older than 40} & 0.257 & $0.568^{* * *}$ & $0.563^{* * *}$ \\
\hline & $(0.437)$ & $(0.077)$ & $(0.076)$ \\
\hline \multirow[t]{2}{*}{ Native born parents } & 0.282 & $0.438^{* * *}$ & $0.432^{* * *}$ \\
\hline & $(0.450)$ & $(0.077)$ & $(0.072)$ \\
\hline \multirow[t]{2}{*}{ Foreign born parents } & 0.277 & $0.847^{* * *}$ & $0.786^{* * *}$ \\
\hline & $(0.448)$ & $(0.089)$ & $(0.084)$ \\
\hline \multirow{2}{*}{ Low education parents } & 0.305 & $0.560^{* * *}$ & $0.546^{* * *}$ \\
\hline & $(0.460)$ & $(0.075)$ & $(0.070)$ \\
\hline \multirow[t]{2}{*}{ High education parents } & 0.176 & $0.675^{* * *}$ & $0.611^{* * *}$ \\
\hline & $(0.381)$ & $(0.095)$ & $(0.091)$ \\
\hline \multirow[t]{2}{*}{ Parents employed at baseline } & 0.175 & $0.465^{* * *}$ & $0.464^{* * *}$ \\
\hline & $(0.380)$ & $(0.072)$ & $(0.070)$ \\
\hline \multirow[t]{2}{*}{ Parents not employed at baseline } & 0.353 & $0.638^{* * *}$ & $0.591^{* * *}$ \\
\hline & $(0.478)$ & $(0.083)$ & $(0.075)$ \\
\hline \multirow[t]{2}{*}{ Parents with prior conviction } & 0.410 & $0.671^{* * *}$ & $0.633^{* * *}$ \\
\hline & $(0.492)$ & $(0.093)$ & $(0.088)$ \\
\hline \multirow[t]{2}{*}{ Parents with no prior conviction } & 0.168 & $0.499^{* * *}$ & $0.489^{* * *}$ \\
\hline & $(0.374)$ & $(0.060)$ & $(0.060)$ \\
\hline \multirow[t]{2}{*}{ Parents charged with a violent offense } & 0.339 & 0.087 & 0.077 \\
\hline & $(0.473)$ & $(0.145)$ & $(0.131)$ \\
\hline \multirow[t]{2}{*}{ Parents charged with a property offense } & 0.312 & $0.501^{* * *}$ & $0.364^{* * *}$ \\
\hline & $(0.463)$ & $(0.108)$ & $(0.096)$ \\
\hline \multirow[t]{2}{*}{ Parents charged with a drug offense } & 0.421 & $1.258^{* * *}$ & $1.150^{* * *}$ \\
\hline & $(0.494)$ & $(0.149)$ & $(0.140)$ \\
\hline \multirow{2}{*}{ Parents charged with a drunk driving offense } & 0.455 & $0.338^{* *}$ & $0.357^{* *}$ \\
\hline & $(0.498)$ & $(0.151)$ & $(0.142)$ \\
\hline Court x Year FE & - & Yes & Yes \\
\hline Baseline Controls & - & No & Yes \\
\hline
\end{tabular}

Note: This table reports first stage results for different samples. See the notes for Table 2 for additional details. $* * *$ $=$ significant at 1 percent level, ${ }^{* *}=$ significant at 5 percent level, ${ }^{*}=$ significant at 10 percent level. 
Appendix Table A5: Subsample Results

\begin{tabular}{|c|c|c|c|c|c|c|}
\hline & Boy & Girl & $\begin{array}{c}\text { Age } \\
11-12\end{array}$ & $\begin{array}{c}\text { Age } \\
13-14\end{array}$ & $\begin{array}{c}\text { Convicted } \\
\text { Father }\end{array}$ & $\begin{array}{l}\text { Convicted } \\
\text { Mother }\end{array}$ \\
\hline \multirow{4}{*}{ Conviction at ages $15-17$} & (1) & $(2)$ & $(3)$ & $(4)$ & (5) & $(6)$ \\
\hline & 0.069 & $0.147^{* *}$ & 0.108 & 0.071 & $0.093^{*}$ & 0.074 \\
\hline & $(0.076)$ & $(0.069)$ & $(0.081)$ & $(0.069)$ & $(0.053)$ & $(0.297)$ \\
\hline & {$[0.307]$} & {$[0.163]$} & {$[0.242]$} & {$[0.231]$} & {$[0.231]$} & {$[0.287]$} \\
\hline \multirow{3}{*}{ Pregnancy at ages $15-17$} & - & $0.060^{* *}$ & 0.047 & 0.066 & 0.037 & 0.338 \\
\hline & & $(0.030)$ & $(0.041)$ & $(0.049)$ & $(0.026)$ & $(0.296)$ \\
\hline & & {$[0.030]$} & {$[0.028]$} & {$[0.032]$} & {$[0.028]$} & {$[0.047]$} \\
\hline \multirow[t]{3}{*}{ High school grad. at age 19} & -0.031 & -0.000 & $-0.398^{*}$ & 0.098 & 0.021 & -0.117 \\
\hline & $(0.125)$ & $(0.123)$ & $(0.222)$ & $(0.092)$ & $(0.091)$ & $(0.369)$ \\
\hline & {$[0.362]$} & {$[0.413]$} & {$[0.385]$} & {$[0.388]$} & {$[0.395]$} & {$[0.312]$} \\
\hline \multirow[t]{3}{*}{ Employment at age 20} & -0.059 & $-0.320^{*}$ & $-0.701^{* *}$ & 0.015 & -0.117 & -0.434 \\
\hline & $(0.120)$ & $(0.164)$ & $(0.284)$ & $(0.111)$ & $(0.087)$ & $(0.640)$ \\
\hline & {$[0.668]$} & {$[0.726]$} & [0.693] & {$[0.699]$} & {$[0.705]$} & {$[0.624]$} \\
\hline Court x Year FE & Yes & Yes & Yes & Yes & Yes & Yes \\
\hline Baseline Controls & Yes & Yes & Yes & Yes & Yes & Yes \\
\hline Observations & 28,479 & 26,845 & 28,633 & 26,691 & 45,255 & 10,069 \\
\hline
\end{tabular}

Note: This table reports two-stage least squares results by child characteristics. Dependent variable means for the children of incarcerated parents are in brackets. See the notes for Table 4 for details on the specification and variables. $* * *=$ significant at 1 percent level, ${ }^{* *}=$ significant at 5 percent level, ${ }^{*}=$ significant at 10 percent level. 
Appendix Table A6: Robustness to Sample Restrictions and Instrument Definition

\begin{tabular}{|c|c|c|c|c|c|}
\hline & \multicolumn{3}{|c|}{ Sample Selection Restrictions } & \multicolumn{2}{|c|}{ Instrument Calculation } \\
\hline & $25+$ Cases & $75+$ Cases & First Time & Split & Reverse \\
\hline & Per Judge & Per Judge & Cases & Sample & Sample \\
\hline Panel A: Child Results & (1) & (2) & (3) & (4) & $(5)$ \\
\hline Conviction at ages $15-17$ & $0.099^{*}$ & 0.077 & 0.092 & 0.113 & $0.085^{*}$ \\
\hline & $(0.052)$ & $(0.049)$ & $(0.087)$ & $(0.074)$ & $(0.051)$ \\
\hline Pregnancy at ages $15-17$ & $\begin{array}{c}0.060^{* *} \\
(0.030)\end{array}$ & $\begin{array}{c}0.056^{*} \\
(0.031)\end{array}$ & $\begin{array}{c}-0.034 \\
(0.040)\end{array}$ & $\begin{array}{c}0.044 \\
(0.038)\end{array}$ & $\begin{array}{c}0.061^{* *} \\
(0.029)\end{array}$ \\
\hline High school grad. at age 19 & $\begin{array}{c}-0.013 \\
(0.087)\end{array}$ & $\begin{array}{r}-0.023 \\
(0.085)\end{array}$ & $\begin{array}{c}-0.077 \\
(0.137)\end{array}$ & $\begin{array}{c}0.086 \\
(0.110)\end{array}$ & $\begin{array}{r}-0.007 \\
(0.085)\end{array}$ \\
\hline Employment at age 20 & $\begin{array}{r}-0.165^{*} \\
(0.096)\end{array}$ & $\begin{array}{c}-0.154 \\
(0.097)\end{array}$ & $\begin{array}{c}0.010 \\
(0.148)\end{array}$ & $\begin{array}{c}-0.059 \\
(0.116)\end{array}$ & $\begin{array}{c}-0.134 \\
(0.093)\end{array}$ \\
\hline Panel B: Parent Results & & & & & \\
\hline Convicted in years 1-6 & $\begin{array}{r}-0.066 \\
(0.092)\end{array}$ & $\begin{array}{r}-0.040 \\
(0.096)\end{array}$ & $\begin{array}{r}-0.102 \\
(0.145)\end{array}$ & $\begin{array}{r}-0.169^{*} \\
(0.099)\end{array}$ & $\begin{array}{c}-0.054 \\
(0.090)\end{array}$ \\
\hline Employment in years 1-6 & $\begin{array}{c}-0.157^{* * *} \\
(0.057)\end{array}$ & $\begin{array}{c}-0.120^{* *} \\
(0.056)\end{array}$ & $\begin{array}{c}-0.229^{* *} \\
(0.096)\end{array}$ & $\begin{array}{c}-0.224^{* * *} \\
(0.079)\end{array}$ & $\begin{array}{c}-0.184^{* * *} \\
(0.059)\end{array}$ \\
\hline Welfare use in years $1-6$ & $\begin{array}{l}0.109^{* *} \\
(0.051)\end{array}$ & $\begin{array}{c}0.061 \\
(0.051)\end{array}$ & $\begin{array}{c}0.101 \\
(0.076)\end{array}$ & $\begin{array}{c}0.109^{*} \\
(0.064)\end{array}$ & $\begin{array}{c}0.129^{* *} \\
(0.052)\end{array}$ \\
\hline Single-adult HH in years $1-6$ & $\begin{array}{c}0.195^{* *} \\
(0.079)\end{array}$ & $\begin{array}{c}0.193^{* *} \\
(0.081)\end{array}$ & $\begin{array}{c}0.273^{* *} \\
(0.117)\end{array}$ & $\begin{array}{c}0.193^{* *} \\
(0.094)\end{array}$ & $\begin{array}{l}0.213^{* * *} \\
(0.078)\end{array}$ \\
\hline Court x Year FE & Yes & Yes & Yes & Yes & Yes \\
\hline Baseline Controls & Yes & Yes & Yes & Yes & Yes \\
\hline Observations & 55,324 & 49,356 & 14,400 & 41,598 & 52,275 \\
\hline
\end{tabular}

Note: This table reports robustness results of our two-stage least squares results. Column 1 restricts the sample to sections who handle at least 25 criminal cases in a given year. Column 2 restricts the sample to sections who handle at least 75 criminal cases in a given year. Column 3 restricts the sample to first time cases. Column 4 calculates judge stringency using a random subset of the data and estimates the treatment effects in the opposing subset of data. Column 5 calculates judge stringency in two equal-sized and mutually exclusive sub-samples and estimates results by stacking the two subsamples. All regressions control for court by year fixed effects and the baseline controls described in Section III. Standard errors are two-way clustered at the parent $(32,455$ cells) and section (604 cells) levels. ${ }^{* * *}=$ significant at 1 percent level, ${ }^{* *}=$ significant at 5 percent level, $*=$ significant at 10 percent level. 


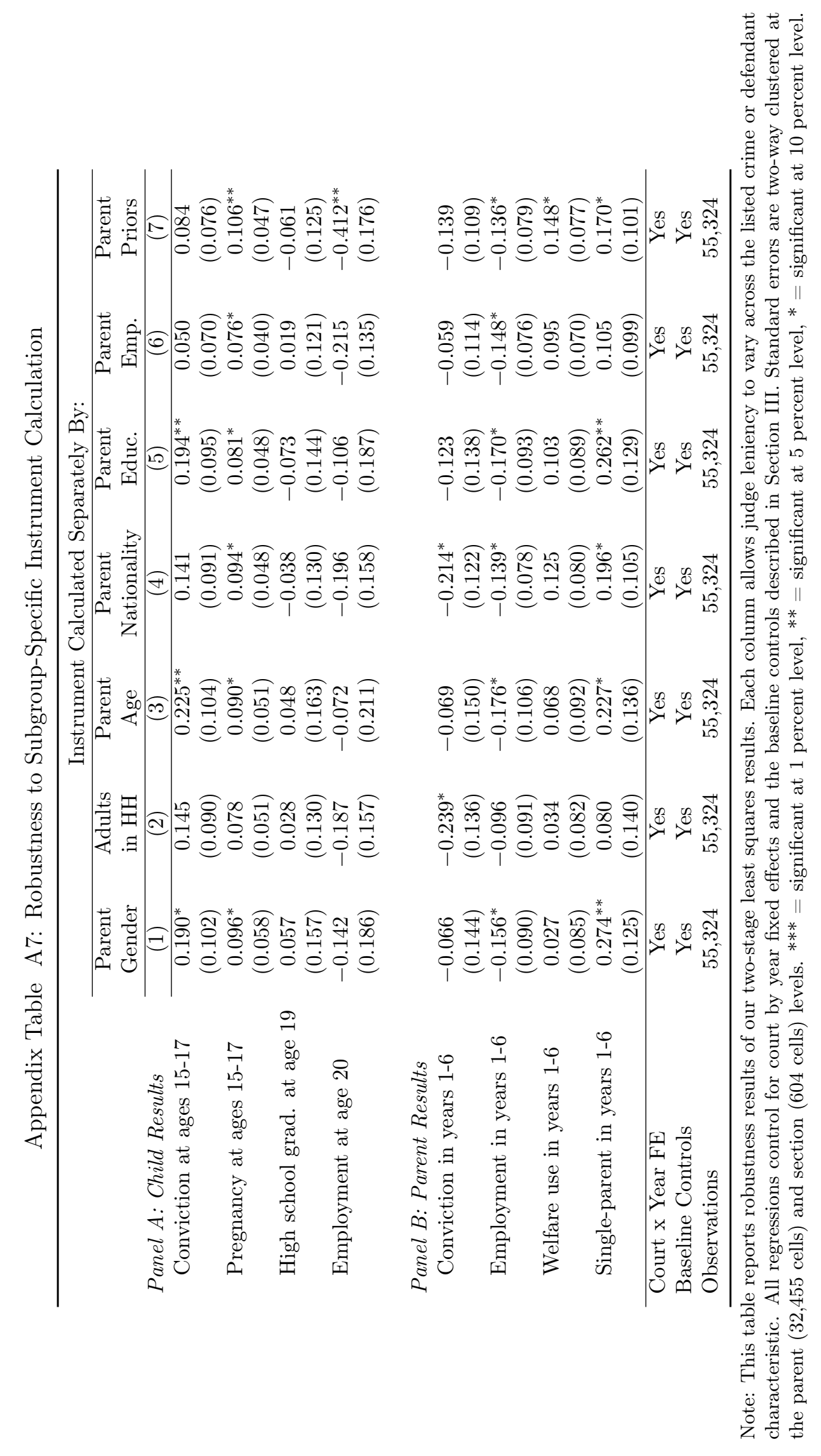


Appendix Table A8: Additional Parent Results

\begin{tabular}{|c|c|c|c|c|c|}
\hline & $\begin{array}{c}\text { Incarcerated } \\
\text { Mean }\end{array}$ & OLS & $\begin{array}{l}\text { OLS w/ } \\
\text { Weights }\end{array}$ & $\begin{array}{l}\text { Reduced } \\
\text { Form }\end{array}$ & 2SLS \\
\hline Panel A: Future crime by type & (1) & $(2)$ & $(3)$ & $(4)$ & $(5)$ \\
\hline Property conviction in years $1-6$ & $\begin{array}{c}0.374 \\
(0.484)\end{array}$ & $\begin{array}{l}0.062^{* * *} \\
(0.006)\end{array}$ & $\begin{array}{l}0.058^{* * *} \\
(0.008)\end{array}$ & $\begin{array}{r}-0.085^{*} \\
(0.044)\end{array}$ & $\begin{array}{c}-0.156^{*} \\
(0.080)\end{array}$ \\
\hline Violent conviction in years 1-6 & $\begin{array}{c}0.191 \\
(0.393)\end{array}$ & $\begin{array}{l}0.038^{* * *} \\
(0.005)\end{array}$ & $\begin{array}{l}0.041^{* * *} \\
(0.006)\end{array}$ & $\begin{array}{l}0.076^{* * *} \\
(0.029)\end{array}$ & $\begin{array}{l}0.139^{* *} \\
(0.056)\end{array}$ \\
\hline Drug conviction in years $1-6$ & $\begin{array}{c}0.298 \\
(0.457)\end{array}$ & $\begin{array}{l}0.068^{* * *} \\
(0.006)\end{array}$ & $\begin{array}{l}0.067^{* * *} \\
(0.008)\end{array}$ & $\begin{array}{c}0.055 \\
(0.033)\end{array}$ & $\begin{array}{c}0.099^{*} \\
(0.060)\end{array}$ \\
\hline Drunk driving conviction in years 1-6 & $\begin{array}{c}0.149 \\
(0.356)\end{array}$ & $\begin{array}{l}0.041^{* * *} \\
(0.004)\end{array}$ & $\begin{array}{l}0.051^{* * *} \\
(0.007)\end{array}$ & $\begin{array}{c}0.035 \\
(0.031)\end{array}$ & $\begin{array}{c}0.064 \\
(0.058)\end{array}$ \\
\hline Reincarcerated in years $1-6$ & $\begin{array}{c}0.539 \\
(0.498)\end{array}$ & $\begin{array}{l}0.199^{* * *} \\
(0.006)\end{array}$ & $\begin{array}{l}0.206^{* * *} \\
(0.008)\end{array}$ & $\begin{array}{c}0.047 \\
(0.040)\end{array}$ & $\begin{array}{c}0.086 \\
(0.069)\end{array}$ \\
\hline \multicolumn{6}{|c|}{ Panel B: Income net of government transfers } \\
\hline Disposable income in years 1-6 & $\begin{array}{c}14.290 \\
(10.717)\end{array}$ & $\begin{array}{c}-3.283^{* * *} \\
(0.188)\end{array}$ & $\begin{array}{c}-3.485^{* * *} \\
(0.413)\end{array}$ & $\begin{array}{r}-1.444 \\
(2.296)\end{array}$ & $\begin{array}{c}-2.632 \\
(4.170)\end{array}$ \\
\hline Court $\mathrm{x}$ Year FE & - & Yes & Yes & Yes & Yes \\
\hline Baseline Controls & - & Yes & Yes & Yes & Yes \\
\hline Observations & 15,536 & 55,324 & 55,324 & 55,324 & 55,324 \\
\hline
\end{tabular}

Note: This table reports OLS, reduced form, and two-stage least squares estimates of the impact of parent incarceration on parent outcomes. The regressions are estimated on the sample as described in the notes to Table 1 Column 1 reports dependent variable means for parents who were incarcerated. Column 2 reports OLS estimates of parental incarceration. Column 3 reports OLS estimates of parental incarceration using weights proportional to the fraction of compliers in a given prior conviction by risk quartile cell. Column 4 reports reduced form estimates of a judge stringency measure that is estimated using data from other cases assigned to a court section in a given year. Column 5 reports two-stage least squares estimates that instrument for parental incarceration using judge stringency. All regressions are run at the child level and control for court by year fixed effects and the baseline controls described in Section III. Standard errors are two-way clustered at the parent $(32,455$ cells $)$ and section $(604$ cells $)$ levels. $* * *=$ significant at 1 percent level, ${ }^{* *}=$ significant at 5 percent level, $*=$ significant at 10 percent level. 
Appendix Table A9: Parent and Non-Parent Results in Different Samples

\begin{tabular}{|c|c|c|c|c|}
\hline & $\begin{array}{c}\text { All } \\
\text { Adults }\end{array}$ & $\begin{array}{l}\text { Sample } \\
\text { Parents }\end{array}$ & $\begin{array}{c}\text { Non-Sample } \\
\text { Parents }\end{array}$ & $\begin{array}{c}\text { Non- } \\
\text { Parents }\end{array}$ \\
\hline & (1) & $(2)$ & $(3)$ & (4) \\
\hline Conviction in years $1-6$ & $\begin{array}{c}-0.084^{* * *} \\
(0.030)\end{array}$ & $\begin{array}{r}-0.066 \\
(0.092)\end{array}$ & $\begin{array}{c}-0.087^{* *} \\
(0.043)\end{array}$ & $\begin{array}{c}-0.095^{* *} \\
(0.037)\end{array}$ \\
\hline Employment in years $1-6$ & $\begin{array}{c}-0.122^{* * *} \\
(0.036)\end{array}$ & $\begin{array}{c}-0.157^{* * *} \\
(0.057)\end{array}$ & $\begin{array}{r}-0.086 \\
(0.052)\end{array}$ & $\begin{array}{c}-0.138^{* * *} \\
(0.047)\end{array}$ \\
\hline Earnings $(\$ 1,000 \mathrm{~s})$ in years $1-6$ & $\begin{array}{c}-5.281^{* * *} \\
(1.340)\end{array}$ & $\begin{array}{c}-7.045^{* *} \\
(2.938)\end{array}$ & $\begin{array}{c}-5.033^{* *} \\
(1.972)\end{array}$ & $\begin{array}{c}-4.892^{\text {*** }} \\
(1.299)\end{array}$ \\
\hline Welfare use in years $1-6$ & $\begin{array}{c}0.029 \\
(0.031)\end{array}$ & $\begin{array}{c}0.109^{*} \\
(0.051)\end{array}$ & $\begin{array}{c}0.028 \\
(0.044)\end{array}$ & $\begin{array}{c}0.010 \\
(0.033)\end{array}$ \\
\hline Single-adult $\mathrm{HH}$ in years $1-6$ & $\begin{array}{c}0.043 \\
(0.038)\end{array}$ & $\begin{array}{l}0.195^{* *} \\
(0.079)\end{array}$ & $\begin{array}{l}0.121^{* *} \\
(0.050)\end{array}$ & $\begin{array}{r}-0.032 \\
(0.041)\end{array}$ \\
\hline Court x Year FE & Yes & Yes & Yes & Yes \\
\hline Baseline Controls & Yes & Yes & Yes & Yes \\
\hline Observations & 340,047 & 55,324 & 119,325 & 165,398 \\
\hline
\end{tabular}

Note: This table reports two-stage least squares results in different samples. The dependent variable is the average over the first six years following the trial. The sample for Column 1 is all adult defendants during our sample period, including those with no children or with children who are excluded from our estimation sample. The sample for Column 2 is the estimation sample of adult defendants described in the notes to Table 1. The sample for Column 3 is the sample of adult defendants with children who are excluded from our estimation sample. The sample for Column 4 is the sample adult defendants with no children. All regressions control for court by year fixed effects and the baseline controls described in Section III. Standard errors are two-way clustered at the adult and section levels. $* * *=$ significant at 1 percent level, ${ }^{* *}=$ significant at 5 percent level, $*=$ significant at 10 percent level. 
Appendix Table A10: Parent Results in Different Time Periods

\begin{tabular}{|c|c|c|c|c|c|}
\hline & $\begin{array}{c}\text { Incarcerated } \\
\text { Mean }\end{array}$ & OLS & $\begin{array}{l}\text { OLS w/ } \\
\text { Weights }\end{array}$ & $\begin{array}{l}\text { Reduced } \\
\text { Form }\end{array}$ & 2SLS \\
\hline Panel A: Years 1-3 after conviction & $(1)$ & $(2)$ & $(3)$ & $(4)$ & $(5)$ \\
\hline Conviction in years $1-3$ & $\begin{array}{c}0.574 \\
(0.495)\end{array}$ & $\begin{array}{l}0.083^{* * *} \\
(0.006)\end{array}$ & $\begin{array}{l}0.089^{* * *} \\
(0.009)\end{array}$ & $\begin{array}{c}-0.099^{* *} \\
(0.047)\end{array}$ & $\begin{array}{c}-0.180^{* *} \\
(0.089)\end{array}$ \\
\hline Employment in years $1-3$ & $\begin{array}{c}0.302 \\
(0.419)\end{array}$ & $\begin{array}{c}-0.094^{* * *} \\
(0.005)\end{array}$ & $\begin{array}{c}-0.090^{* * *} \\
(0.007)\end{array}$ & $\begin{array}{c}-0.090^{* * *} \\
(0.034)\end{array}$ & $\begin{array}{c}-0.165^{* * *} \\
(0.059)\end{array}$ \\
\hline Earnings $(\$ 1,000 \mathrm{~s})$ in years $1-3$ & $\begin{array}{c}5.423 \\
(12.553)\end{array}$ & $\begin{array}{c}-2.800^{* * *} \\
(0.174)\end{array}$ & $\begin{array}{c}-2.805^{* * *} \\
(0.370)\end{array}$ & $\begin{array}{c}-3.443^{* *} \\
(1.419)\end{array}$ & $\begin{array}{c}-6.273^{* *} \\
(2.597)\end{array}$ \\
\hline Welfare use in years $1-3$ & $\begin{array}{c}0.573 \\
(0.441)\end{array}$ & $\begin{array}{l}0.078^{* * *} \\
(0.005)\end{array}$ & $\begin{array}{l}0.080^{* * *} \\
(0.007)\end{array}$ & $\begin{array}{c}0.039 \\
(0.032)\end{array}$ & $\begin{array}{c}0.071 \\
(0.057)\end{array}$ \\
\hline Single-adult $\mathrm{HH}$ in years $1-3$ & $\begin{array}{c}0.720 \\
(0.418)\end{array}$ & $\begin{array}{l}0.089^{* * *} \\
(0.006)\end{array}$ & $\begin{array}{l}0.099^{* * *} \\
(0.009)\end{array}$ & $\begin{array}{c}0.098^{*} \\
(0.052)\end{array}$ & $\begin{array}{r}0.178^{*} \\
(0.094)\end{array}$ \\
\hline \multicolumn{6}{|l|}{ Panel B: Years 4-6 after conviction } \\
\hline Conviction in years $4-6$ & $\begin{array}{c}0.646 \\
(0.478)\end{array}$ & $\begin{array}{l}0.073^{* * *} \\
(0.006)\end{array}$ & $\begin{array}{l}0.081^{* * *} \\
(0.008)\end{array}$ & $\begin{array}{r}-0.034 \\
(0.049)\end{array}$ & $\begin{array}{r}-0.062 \\
(0.087)\end{array}$ \\
\hline Employment in years $4-6$ & $\begin{array}{c}0.341 \\
(0.410)\end{array}$ & $\begin{array}{c}-0.064^{* * *} \\
(0.005)\end{array}$ & $\begin{array}{c}-0.061^{* * *} \\
(0.008)\end{array}$ & $\begin{array}{c}-0.082^{* *} \\
(0.035)\end{array}$ & $\begin{array}{c}-0.153^{* *} \\
(0.067)\end{array}$ \\
\hline Earnings $(\$ 1,000 \mathrm{~s})$ in years $4-6$ & $\begin{array}{c}7.485 \\
(14.822)\end{array}$ & $\begin{array}{c}-2.467^{* * *} \\
(0.206)\end{array}$ & $\begin{array}{c}-2.424^{* * *} \\
(0.376)\end{array}$ & $\begin{array}{c}-4.004^{* *} \\
(1.777)\end{array}$ & $\begin{array}{c}-7.424^{* *} \\
(3.429)\end{array}$ \\
\hline Welfare use in years $4-6$ & $\begin{array}{c}0.474 \\
(0.407)\end{array}$ & $\begin{array}{l}0.054^{* * *} \\
(0.005)\end{array}$ & $\begin{array}{l}0.050^{* * *} \\
(0.007)\end{array}$ & $\begin{array}{l}0.068^{* *} \\
(0.030)\end{array}$ & $\begin{array}{l}0.125^{* *} \\
(0.058)\end{array}$ \\
\hline Single-adult $\mathrm{HH}$ in years $4-6$ & $\begin{array}{c}0.696 \\
(0.402)\end{array}$ & $\begin{array}{l}0.091^{* * *} \\
(0.006)\end{array}$ & $\begin{array}{l}0.103^{* * *} \\
(0.009)\end{array}$ & $\begin{array}{l}0.111^{* *} \\
(0.044)\end{array}$ & $\begin{array}{l}0.207^{* *} \\
(0.081)\end{array}$ \\
\hline Court x Year FE & - & Yes & Yes & Yes & Yes \\
\hline Baseline Controls & - & Yes & Yes & Yes & Yes \\
\hline Observations & 15,536 & 55,324 & 55,324 & 55,324 & 55,324 \\
\hline
\end{tabular}

Note: This table reports OLS, reduced form, and two-stage least squares estimates of the impact of parent incarceration on the parent's own outcomes. The regressions are estimated on the sample as described in the notes to Table 1. Column 1 reports dependent variable means for parents who were incarcerated. Column 2 reports OLS estimates of parental incarceration. Column 3 reports OLS estimates of parental incarceration using weights proportional to the fraction of compliers in a given prior conviction by risk quartile cell. Column 4 reports reduced form estimates of a judge stringency measure that is estimated using data from other cases assigned to a court section in a given year. Column 5 reports two-stage least squares estimates that instrument for parental incarceration using judge stringency. All regressions are run at the child level and control for court-by-year fixed effects and the baseline controls described in Section III. Standard errors are two-way clustered at the parent $(32,455$ cells $)$ and section $(604$ cells $)$ levels. $* * *=$ significant at 1 percent level, ${ }^{* *}=$ significant at 5 percent level, $*=$ significant at 10 percent level. 
Appendix Table A11: Additional Results by Family Disadvantage

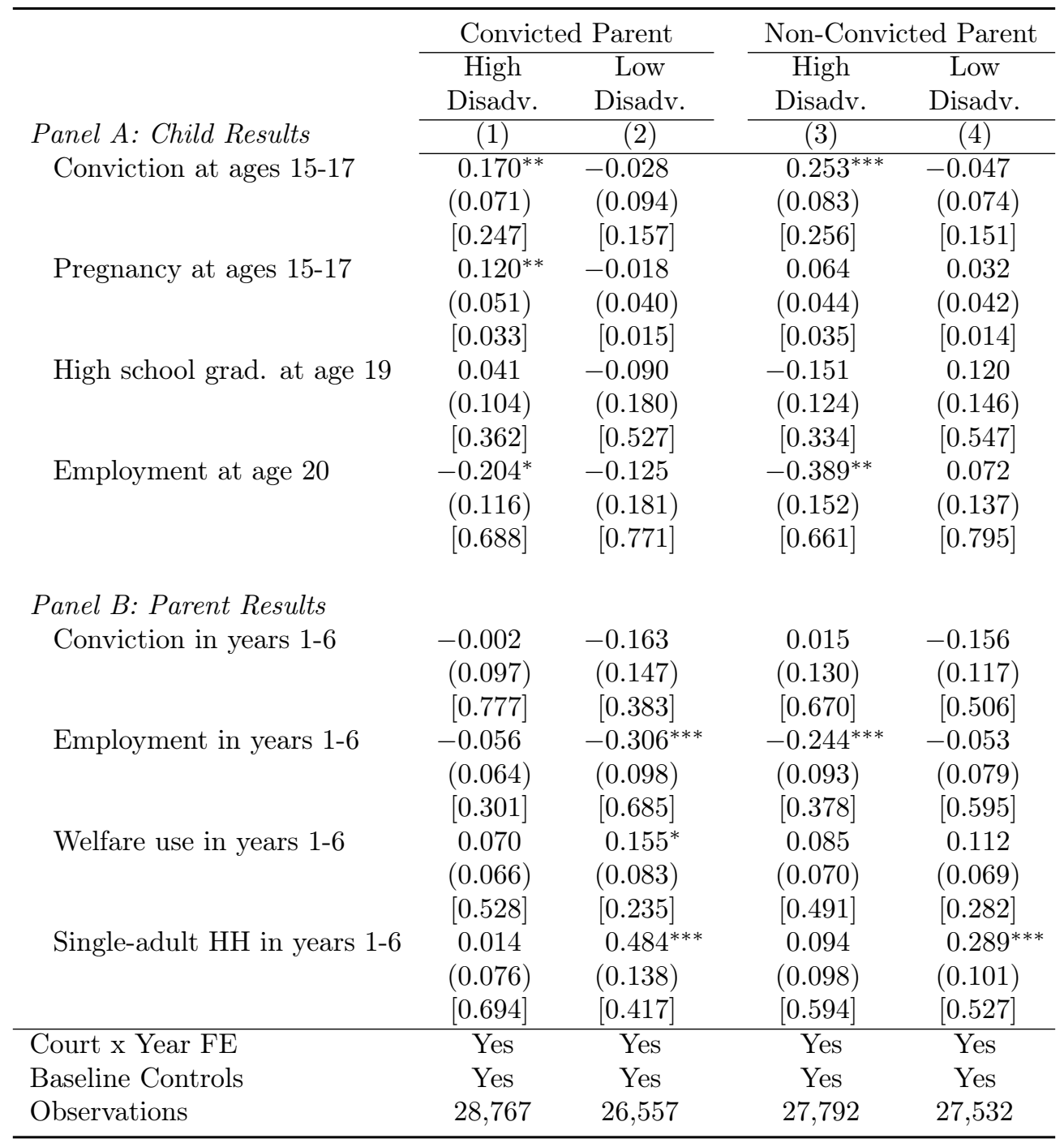

Note: This table reports additional two-stage least squares results by family disadvantage. We measure family disadvantage using an index of standardized baseline parental education, parental employment, parental criminal history, and history of parental drug and alcohol abuse for both biological parents. High and low disadvantage are defined using the median of the standardized index. Dependent variable means for the incarcerated group are in brackets. See the notes for Tables 46 for details on the specification and variables. $* * *=$ significant at 1 percent level, ${ }^{* *}=$ significant at 5 percent level, $*=$ significant at 10 percent level. 


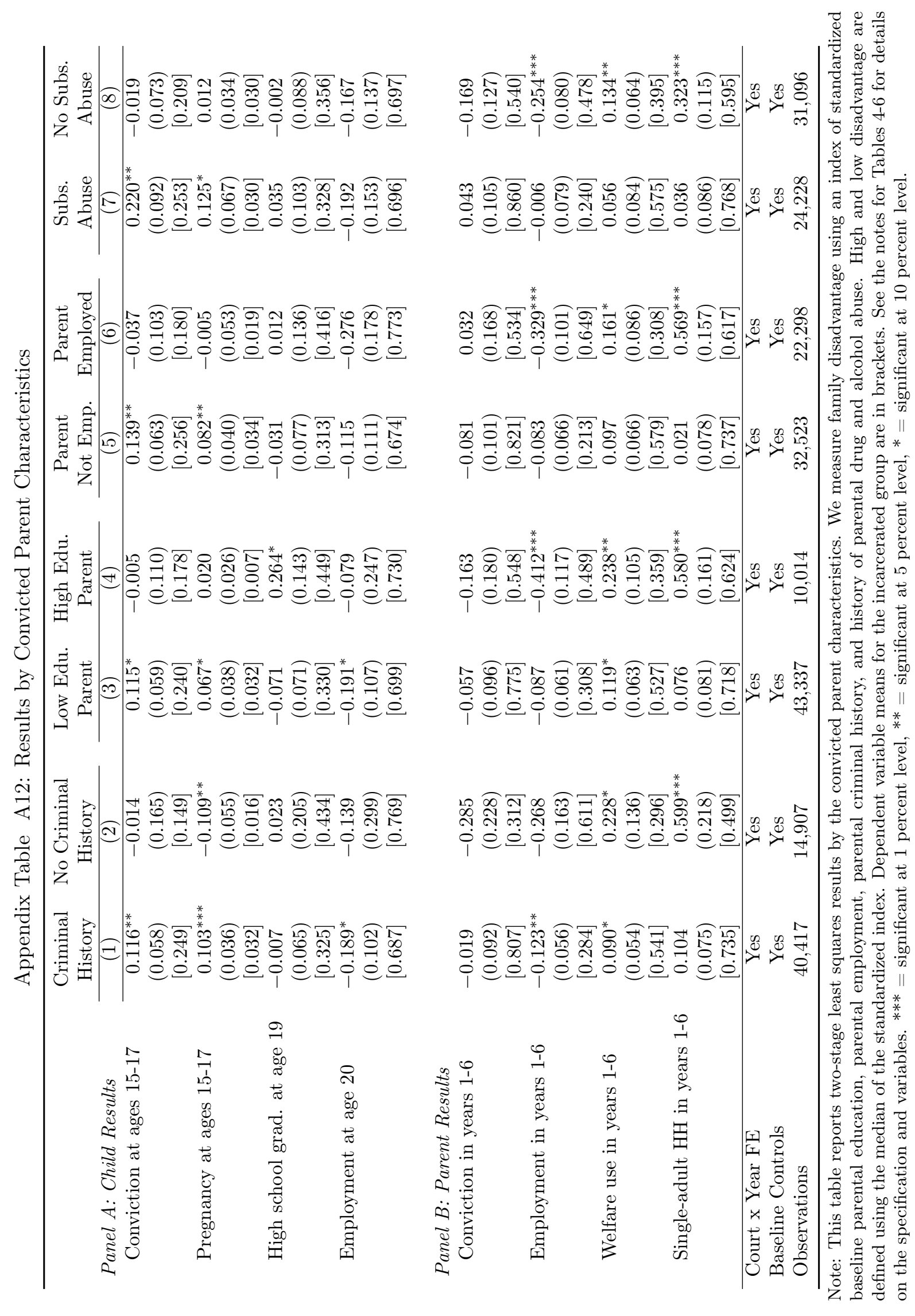




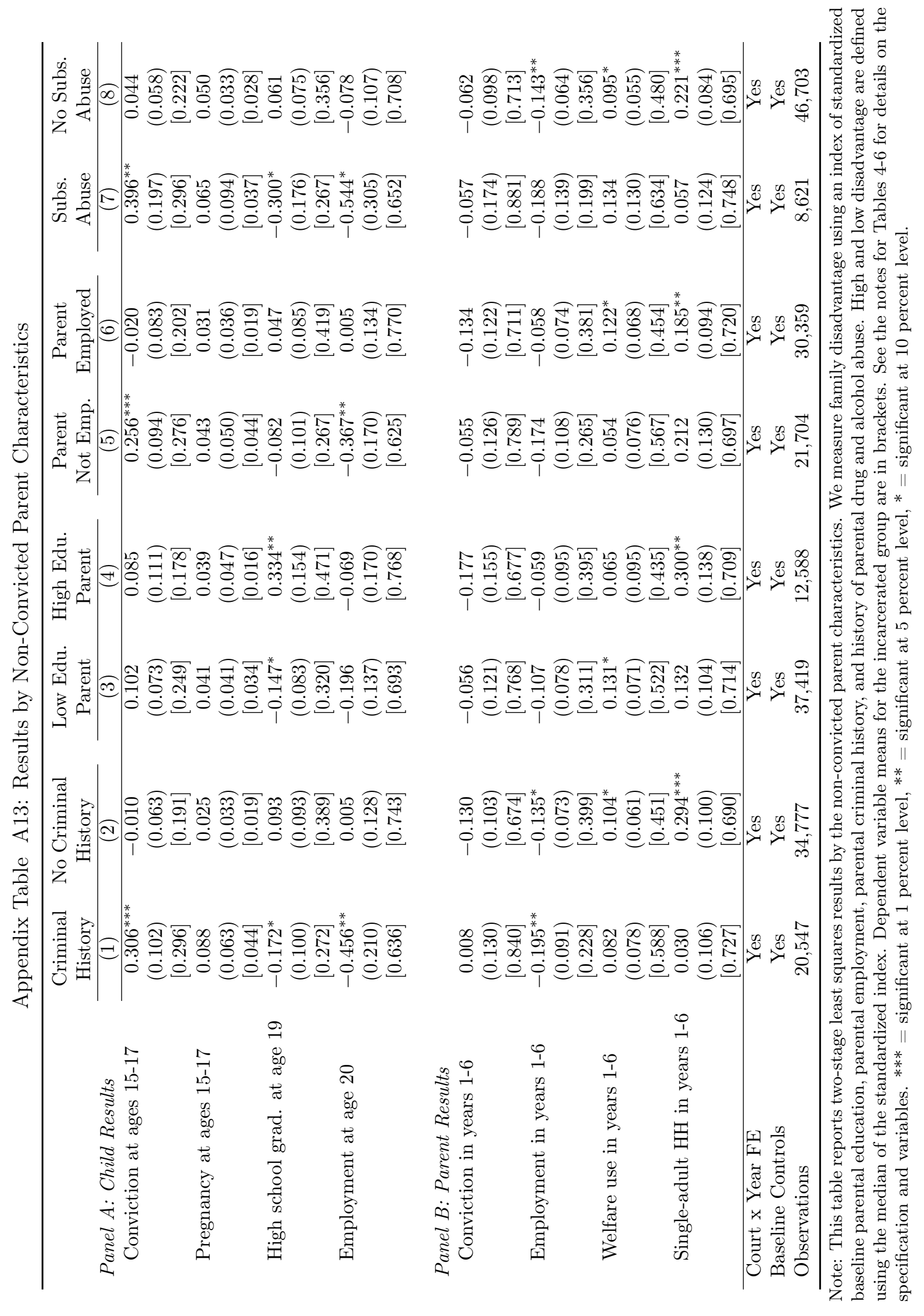


Appendix Table A14: Results by Both Convicted and Non-Convicted Parent Characteristics

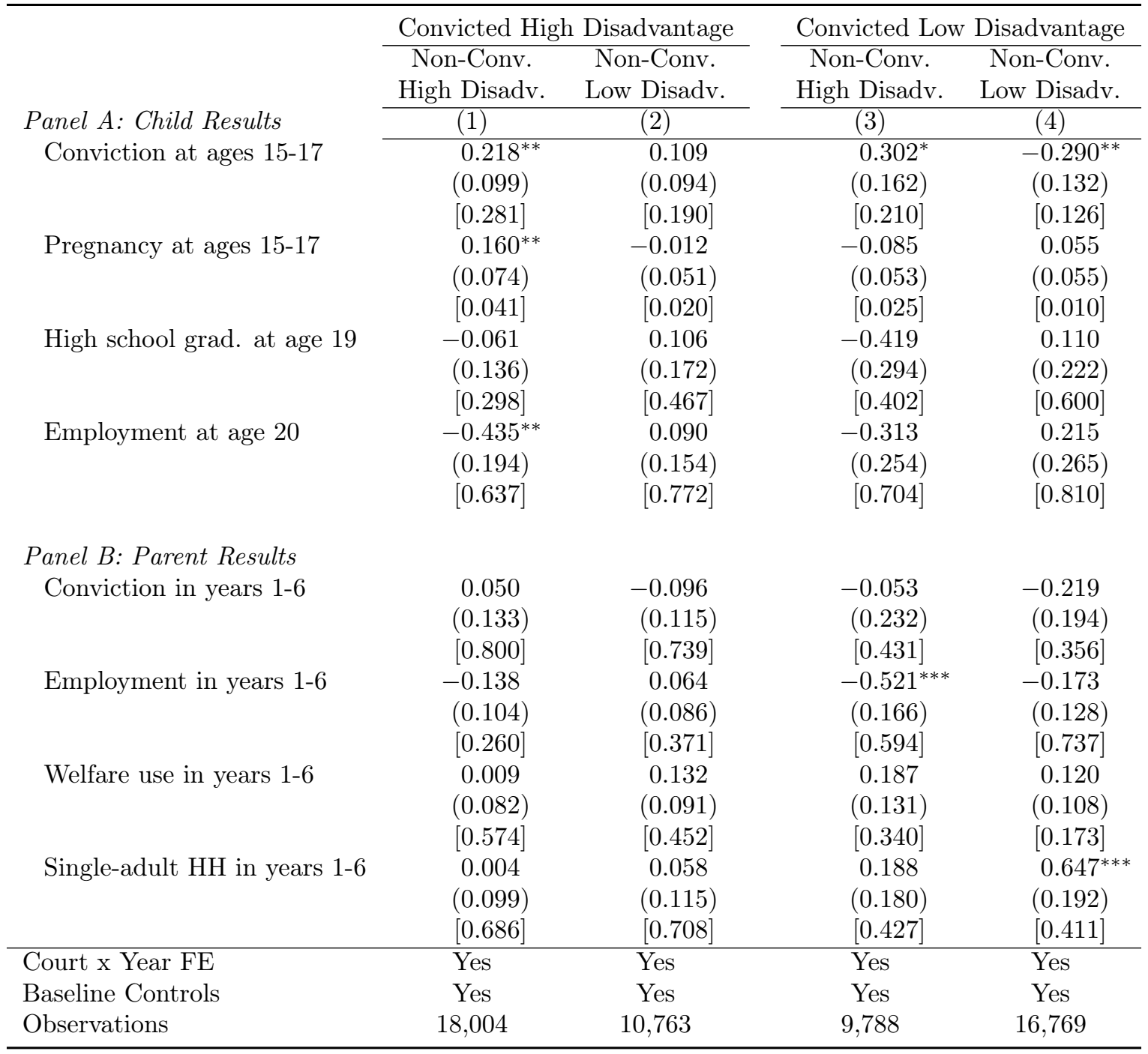

Note: This table reports two-stage least squares results by both convicted and non-convicted parent characteristics. We measure family disadvantage for both biological parents separately using an index of standardized baseline parental education, parental employment, parental criminal history, and history of parental drug and alcohol abuse. High and low disadvantage are defined using the median of the standardized index. Dependent variable means for the incarcerated group are in brackets. See the notes for Tables 4.6 for details on the specification and variables. ${ }^{* * *}=$ significant at 1 percent level, $* *=$ significant at 5 percent level, $*=$ significant at 10 percent level. 


\section{Appendix Figure A1: Criminal Case Process in Sweden}

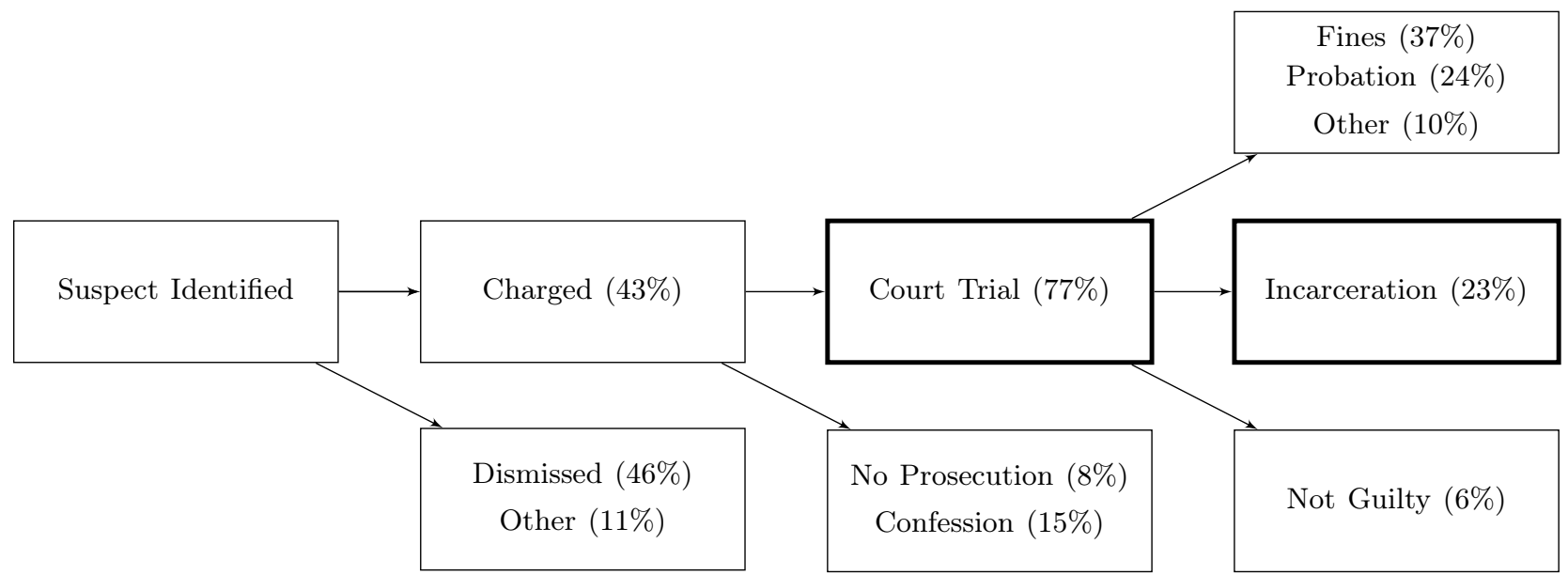

Note: This figure illustrates the criminal case process in Sweden. The figure reports percentages for 2004. 
Appendix Figure A2: Trends in Incarceration Rates

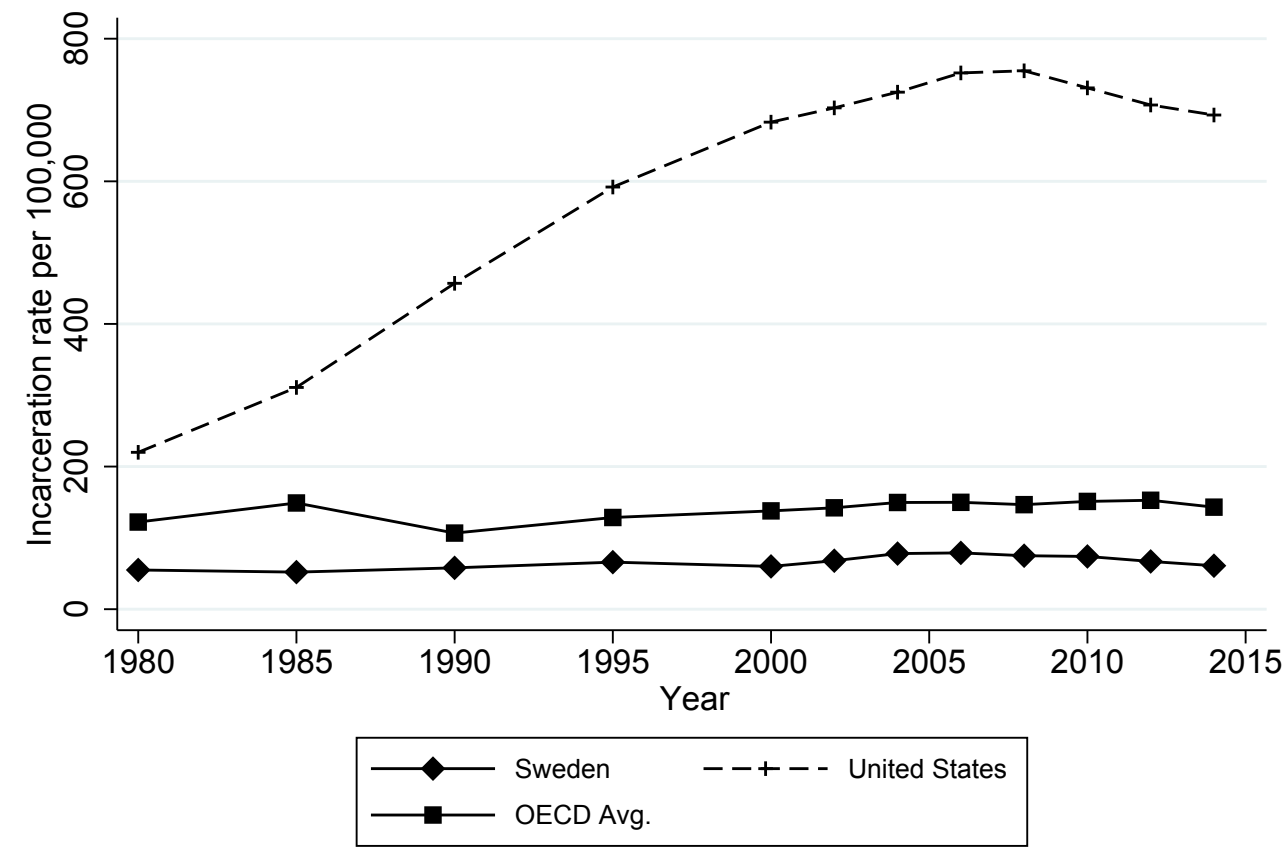

Note: This figure plots incarceration rates per 100,000 individuals. Prior to 2000, the OECD average does not include Germany and Switzerland. The OECD average is not population weighted. Canadian estimates are lagged one year due to differences in reporting. Source: Institute for Criminal Policy Research. 
Appendix Figure A3: Incarceration Costs by Country

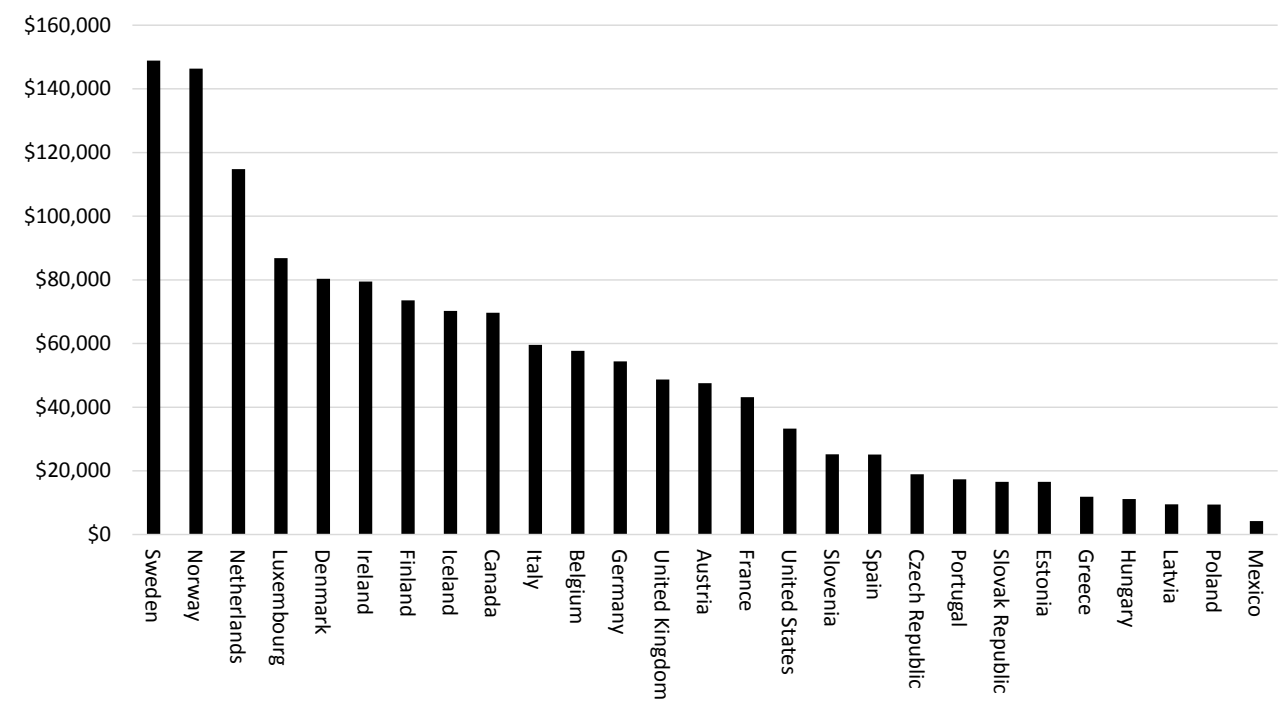

Note: This figure plots annual per inmate costs for the most recent year available. Estimates for Mexico are based on entire judicial budget rather than prison estimates and thus most likely overestimate cost per year. Sources: Institute of Public Affairs and Descifrando el Gasto Publico en Seguridad-Ethos laboratorio de Politicals Publicas. 
Appendix Figure A4: Distribution of Judge Stringency and First Stage

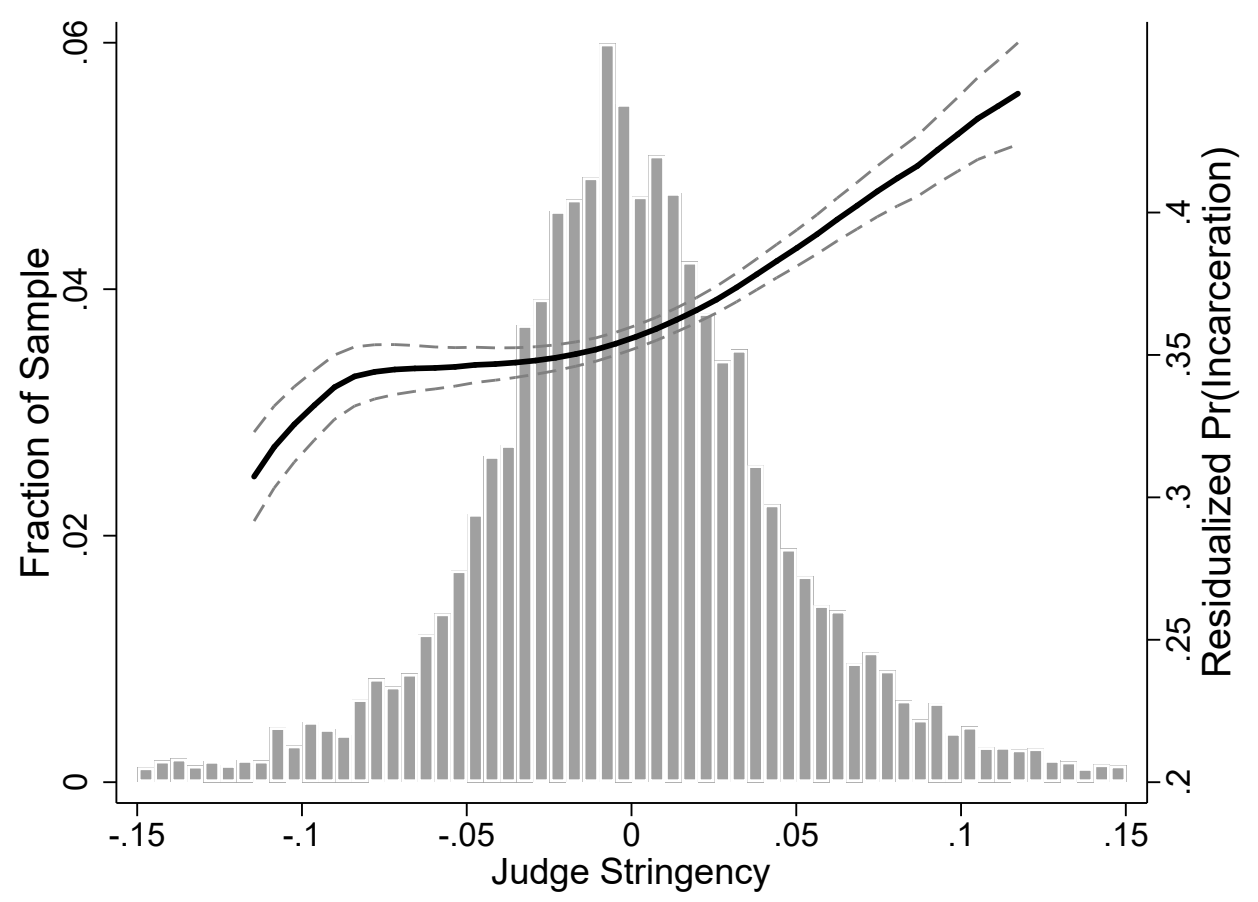

Note: This figure reports the distribution of the judge stringency measure that is estimated using data from other cases assigned to a judge in the same year following the procedure described in Section III. The solid line shows a local linear regression of incarceration on judge stringency. The dashed lines show 90 percent confidence intervals. 
Appendix Figure A5: Probability of Child and Parent Earnings Above Threshold

Panel A: Child Earnings (\$) at Age 20

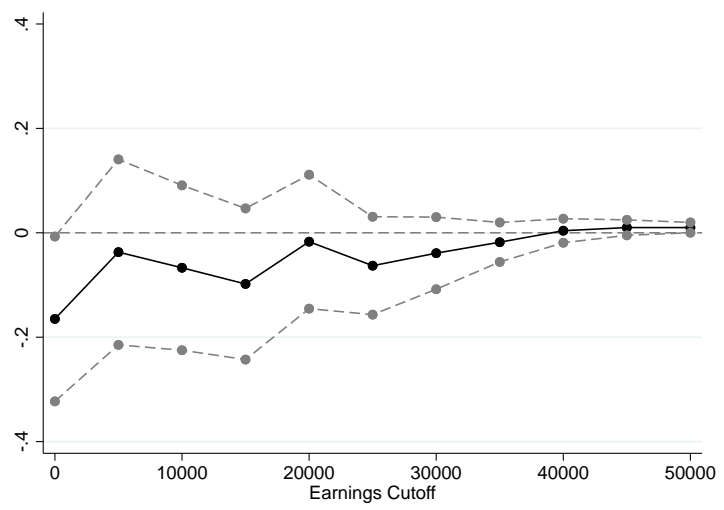

Panel B: Parent Earnings (\$) in Years 1-6

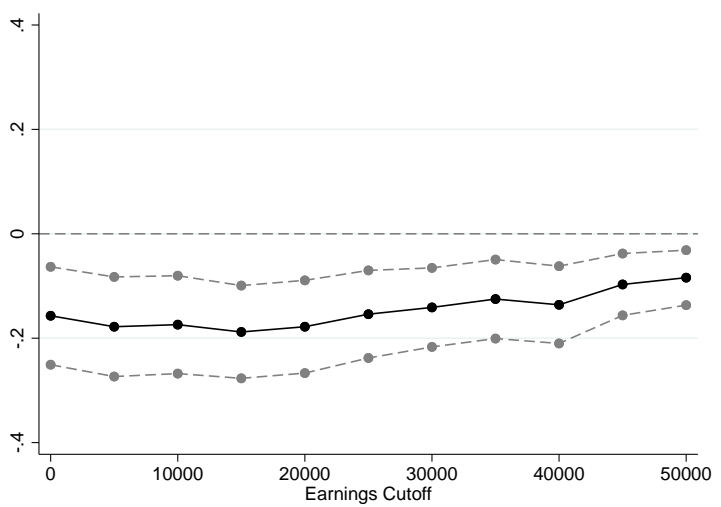

Note: This figure reports two-stage least squares estimates and corresponding 90 percent confidence intervals for the impact of parental incarceration on the probability of having earnings above each income threshold. See the text for additional details. 


\section{Appendix B: Interpreting our LATE}

This section includes additional details on how we calculate the number and characteristics of those who are always takers, never takers, and compliers in our sample. As described in the main text, we then use the share of compliers relative to the share of the estimation sample as weights when estimating our OLS specifications.

Overview: Following Dahl et al. (2014), we define compliers as children whose parents incarceration decision would have been different had their case been assigned to the most strict instead of the least strict judge:

$$
\pi_{c}=\operatorname{Pr}\left(\operatorname{Prison}_{i}=1 \mid Z_{i}=\bar{z}\right)-\operatorname{Pr}\left(\operatorname{Prison}_{i}=1 \mid Z_{i}=\underline{z}\right)=\operatorname{Pr}\left(\operatorname{Prison}_{i}(\bar{z})>\operatorname{Prison}_{i}(\underline{z})\right)
$$

where $\bar{z}$ represents the maximum value of our judge instrument (the most stringent judge) and $\underline{z}$ represents the minimum value of our instrument (the least stringent judge).

Always takers are children whose parents would always be incarcerated regardless of the judge assigned to their case. Because of the monotonicity and independence assumptions, the fraction of always takers is given by the probability of a parent being incarcerated for the least stringent judge:

$$
\pi_{a}=\operatorname{Pr}\left(\operatorname{Prison}_{i}=1 \mid Z_{i}=\underline{z}\right)=\operatorname{Pr}\left(\operatorname{Prison}_{i}(\bar{z})=\operatorname{Prison}_{i}(\underline{z})=1\right)
$$

Finally, never takers are children whose parents would never be incarcerated, with the fraction of never takers given by the probability of not being incarcerated by the most stringent judge:

$$
\pi_{n}=\operatorname{Pr}\left(\operatorname{Prison}_{i}=0 \mid Z_{i}=\bar{z}\right)=\operatorname{Pr}\left(\operatorname{Prison}_{i}(\bar{z})=\operatorname{Prison}_{i}(\underline{z})=0\right)
$$

Number of Compliers: We calculate the shares of children in each category by looking at the rates of parental incarceration for the "most lenient" and "most strict" judges. In Table B1, we estimate our linear specification of the first stage of incarceration on our residualized measure of judge stringency controlling for our exhaustive court-by-time fixed effects, under different definitions of the most lenient and most stringent judges. Under our preferred specification where we define most lenient judge as the bottom 1 percentile of judge stringency and the most strict judge as the top 1 percentile of judge stringency, we find that 16 percent of our sample are compliers, 64 percent are never takers, and 20 percent are always takers.

Characteristics of Compliers: We also characterize our population of compliers by observable characteristics, which can be recovered by calculating the fraction of compliers in different subsamples (Abadie 2003, Dahl et al. 2014). We find that compliers are significantly more likely to be of high socioeconomic status and have a drunk driving offense. Compliers are also somewhat less likely to be a first-time offender. 


\section{Appendix B References}

[1] Abadie, Alberto. 2003. "Semiparametric Instrumental Variable Estimation of Treatment Response Models." Journal of Econometrics, 113(2): 231-263.

[2] Dahl, Gordon B., Andreas Ravndal Kostøl, and Magne Mogstad. 2014. "Family Welfare Cultures." Quarterly Journal of Economics, 129(4): 1711-1752. 


\section{Appendix Table B1: Sample Share by Compliance Type}

\begin{tabular}{lccc}
\hline & 1 percent & 1.5 percent & 2 percent \\
\cline { 2 - 4 } Compliers & 0.162 & 0.147 & 0.131 \\
Never takers & 0.646 & 0.651 & 0.657 \\
Always takers & 0.192 & 0.202 & 0.212 \\
\hline
\end{tabular}

Note: This table reports the the share of always takers, never takers, and compliers in our sample. Compliers are defined as convicted parents whose prison sentences decision would have been different had their case been assigned to the most lenient instead of the most strict judge. Always takers are instead parents who would never be released regardless of the judge assigned to their case. Finally, never takers are parents who would never be incarcerated regardless of the stringency of the judge. Following Dahl et al. (2014) we calculate the shares of parents in each category by looking at the prison rates for parents assigned to the most lenient and most strict judges. We define the most lenient judge as the bottom $1 / 1.5 / 2$ percentile of judge stringency and the most strict judge as the top $1 / 1.5 / 2$ percentile of judge stringency. We estimate our linear specification of the first stage to recover compliers as the share of parents predicted to get incarcerated at the top percentile minus the share of parents predicted to get incarcerated at the bottom percentile, always takers as the share of parents predicted to be sentenced to prison at the bottom percentile and never takers as the share of parents who are predicted to be released at the top percentile. 
Appendix Table B2: Characteristics of Marginal Defendants and Their Children

Child is native born

Child is foreign born

\begin{tabular}{ccc}
$P[X=x]$ & $P[X=x \mid$ complier $]$ & $\frac{P[X=x \mid \text { complier }]}{P[X=x]}$ \\
\hline 0.911 & 0.911 & 1.000 \\
$(0.001)$ & $(0.016)$ & $(0.017)$ \\
0.089 & 0.089 & 0.999 \\
$(0.001)$ & $(0.016)$ & $(0.176)$
\end{tabular}

Low education parent

0.815

0.786

$(0.002)$

$(0.023)$

0.965

High education parent

0.185

0.214

(0.002)

$(0.023)$

(0.028)

0.466

0.540

$(0.002)$

$(0.030)$

1.154

Parent with prior conviction

0.534

$(0.002)$

0.460

$(0.030)$

0.407

0.333

$(0.125)$

1.159

(0.064)

Parent with no prior conviction

$(0.002)$

(0.030)

0.861

Parent employed at baseline

0.593

0.667

$(0.056)$

Parent not employed at baseline

$(0.002)$

$(0.030)$

0.819

0.150

0.023

$(0.002)$

$(0.033)$

Parent charged with non-violent offense

0.850

$(0.002)$

0.977

$(0.033)$

$(0.074)$

0.070

0.158

$(0.001)$

(0.018)

0.930

0.842

$(0.001)$

$(0.018)$

1.124

0.192

0.161

$(0.051)$

0.156

$(0.220)$

1.149

(0.039)

2.274

$(0.250)$

0.905

Parent charged with property offense

$(0.002)$

$(0.022)$

$(0.019)$

0.808

0.839

0.841

Parent charged with non-property offense

$(0.002)$

$(0.022)$

$(0.115)$

0.126

0.074

1.038

Parent charged with drunk driving offense

$(0.001)$

$(0.024)$

$(0.027)$

0.874

0.926

0.586

Parent charged with non-drunk driving offense

$(0.001)$

$(0.024)$

$(0.187)$

1.060

$(0.027)$

Note: This table presents the sample distribution, complier distribution, and relative likelihood for different subgroups. Bootstrapped standard errors in parentheses are obtained using 500 replications. 


\section{Appendix C: Social Cost Calculations}

This section includes additional details on the long-run social cost calculations described in the main text. We caution that these long-run calculations are speculative for at least two reasons. First, the correlation between early-life outcomes and long-term earnings may either under or overstate the causal impact of parental incarceration on long-term earnings. Second, many of our two-stage least squares estimates are imprecise and, as a result, the confidence interval surrounding our long-term cost calculation is large.

\section{A. Parent Outcomes}

Lost Parental Earnings: In Table 6, we estimate that incarceration decreases annual formal sector earnings over the first six years by $\$ 7,045$ for the marginally incarcerated parent. Following Chetty, Hendren, and Katz (2016), we assume this effect is constant over the rest of the lifetime and discount future earnings through age 64 back to age 40, the mean age in our sample, using a discount rate of 3 percent. These calculations imply incarcerated parents earn $\$ 126,356$ less in present value over their remaining years in the labor force.

Social Cost of New Parental Crime: We estimate the social cost of future parental crime using our crime-specific estimates in Table A8, These estimates show that the marginally incarcerated parent is 13.9 percentage points more likely to be convicted of a violent crime, 9.9 percentage points more likely to be convicted of a drug crime, and 6.4 percentage points more likely to be convicted of a drunk driving crime. Incarcerated parents are also 15.6 percentage points less likely to be convicted of a property crime. We then multiply each crime-specific two-stage least squares estimate by the lower and upper bound cost of crime estimates from Mueller-Smith (2015). To be conservative in our social cost estimates, we assume violent crimes are assaults and property crimes are larceny, the two crimes in their category with the lowest estimated social costs. Aggregating across these measures, we find a lower bound social cost of crime of $\$ 6,114$ and an upper bound of $\$ 15,626$.

Social Cost of New Parental Welfare Payments: We estimate the social cost of future welfare payments using the two-stage least squares estimate from Table6. These results show that incarcerated parents are 10.9 percentage points more likely to receive welfare over the first six years following their trial. Following our earnings calculation, we assume this effect is constant over the rest of the lifetime and discount future welfare use through age 64 back to age 40, the mean age in our sample, using a discount rate of 3 percent. We also assume that average welfare payments over the lifetime are $\$ 10,968$, as reported in OECD statistics. These calculations suggest that the total increase in welfare payments for an incarcerated parent are equal to $\$ 21,442$ in present value.

However, the social costs of these additional social assistance payments are restricted to the taxinduced distortions of financing the social welfare system. We estimate the costs of these distortions using information from Kleven and Kreiner (2003), who calculate the marginal cost of public funds (MCF) in Sweden to be approximately 1.74 after accounting for labor supply responses on both 
the intensive and extensive margin. This estimate implies that the social cost of the new welfare payments is $74 \%$ of the monetary cost of any social assistance payments, or $\$ 15,867$ in present value.

\section{B. Child Outcomes}

Lost Child Earnings: In Table 5, we estimate that parental incarceration decreases earnings at age 20 by $\$ 1,654$. Early-life earnings are only weakly correlated with lifetime earnings, however, making it difficult to accurately measure the impact of parental incarceration over all years in the labor market using only this estimate. We therefore impute earnings effects at longer time horizons using the correlation between earnings at 25, 30, and 35, and several of our early-life outcomes (see Appendix Table C1). Specifically, we multiply each correlation with its corresponding two-stage least square estimate from Tables 4 and 5 to generate the imputed impact of parental incarceration at each age.

We then use the observed effect of parental incarceration at age 20 and the imputed effects at ages 25, 30, and 35 to calculate the impact of parental incarceration on lifetime earnings. Following our calculation for lost parental earnings, we assume a constant treatment effect after age 35 and discount future earnings through age 64 using a discount rate of 3 percent. These calculations imply that the children of incarcerated parents earn $\$ 36,471$ less in present value over their years in the labor force.

Social Cost of New Child Crime: We estimate the social costs of future child crime using our crime-specific estimates from Table 4 and the social costs by crime type compiled by Mueller-Smith (2015). We again use the lowest cost estimate for each major crime type (e.g., the costs of assaults for violent crime) to provide a conservative estimate of these costs. Table $\mathrm{C} 2$ presents these crimespecific estimates and the upper and lower bound cost estimates by crime type used to calculate social costs. Aggregating across all crime types, we find that the social cost of new child crime is between $\$ 4,005$ and $\$ 9,406$.

Social Cost of New Child Welfare Payments: We estimate the social cost of future welfare payments for children using the two-stage least squares estimate from Table 5 . These results show that parental incarceration increases welfare use at age 20 by 9.6 percentage points. Unlike our earnings calculation, we assume this effect is constant over the rest of the lifetime and discount future welfare use through age 64 using a discount rate of 3 percent. We again assume that average welfare payments over the lifetime are $\$ 10,968$ and that there are no tax-induced distortions to the economy. These calculations imply that the total increase in welfare payments is equal to $\$ 22,269$ per child in present value. Following the calculations outlined above, the social cost of these new welfare payments is equal to $\$ 16,479$ per child.

Social Cost of New Child Pregnancy: We estimate the social cost of teenage pregnancy for children using the two-stage least squares estimate from Table 4. These results show that parental incarceration increases teen pregnancy by 6.0 percentage points. Using the estimated cost of a teenage 
pregnancy of $\$ 21,804$ from Chaaban and Cunningham (2011), this implies an additional social cost of $\$ 1,308$ for the parents of female children.

\section{Total Social Cost Calculations}

We combine our social cost estimates for lost earnings, increased social assistance usage, new crime, and new pregnancy to estimate the total social cost of parental incarceration. Based on our above assumptions, social costs for the incarcerated parent ranges from $\$ 148,337$ to $\$ 157,849$ and social costs for each child ranges from $\$ 58,265$ to $\$ 63,665$. If we multiply the social cost per child by the average number of children for families in our sample (2.767), this implies that the total social cost of parental incarceration is between $\$ 309,556$ and $\$ 334,010$ per family.

\section{Appendix C References}

[1] Chaaban, Jad, and Wendy Cunningham. 2011. "Measuring the Economic Gain of Investing in Girls." World Bank Policy Research Working Paper 5753.

[2] Chetty, Raj, Nathaniel Hendren, and Lawrence F. Katz. 2016. "The Effects of Exposure to Better Neighborhoods on Children: New Evidence from the Moving to Opportunity Experiment." American Economic Review, 106(4): 855-902.

[3] Kleven, Henrik J., and Claus Kreiner. 2003. "The Marginal Cost of Public Funds in OECD Countries: Hours of Work Versus Labor Force Participation." CESifo Working Paper 935.

[4] Mueller-Smith, Michael. 2015. "The Criminal and Labor Market Impacts of Incarceration." Unpublished Working Paper. 
Appendix Table C1: Correlation Between Early-Life Outcomes and Long-Run Earnings

\begin{tabular}{cccc}
\hline & $\begin{array}{c}\text { Earnings } \\
\text { at age 25 }\end{array}$ & $\begin{array}{c}\text { Earnings } \\
\text { at age 30 }\end{array}$ & $\begin{array}{c}\text { Earnings } \\
\text { at age 35 }\end{array}$ \\
\cline { 2 - 4 } Convicted at ages 15-17 & $(1)$ & $(2)$ & $(3)$ \\
\cline { 2 - 4 } & $-1.860^{* * *}$ & $-4.172^{* * *}$ & $-5.067^{* * *}$ \\
Pregnancy at ages 15-17 & $(0.129)$ & $(0.164)$ & $(0.213)$ \\
& $(0.317)$ & $(0.408)$ & $(0.527)$ \\
High school graduate at 19 & $2.978^{* * *}$ & $6.933^{* * *}$ & $8.792^{* * *}$ \\
Employed at age 20 & $(0.089)$ & $(0.116)$ & $(0.159)$ \\
& $6.268^{* * *}$ & $5.964^{* * *}$ & $7.132^{* * *}$ \\
\hline Dep. Variable Mean & $(0.100)$ & $(0.132)$ & $(0.176)$ \\
\hline
\end{tabular}

Note: This table reports correlations between early-life outcomes and earnings at different ages. $* * *=$ significant at 1 percent level, $* *=$ significant at 5 percent level, $*=$ significant at 10 percent level. 
Appendix Table C2: Details of Social Cost Calculations

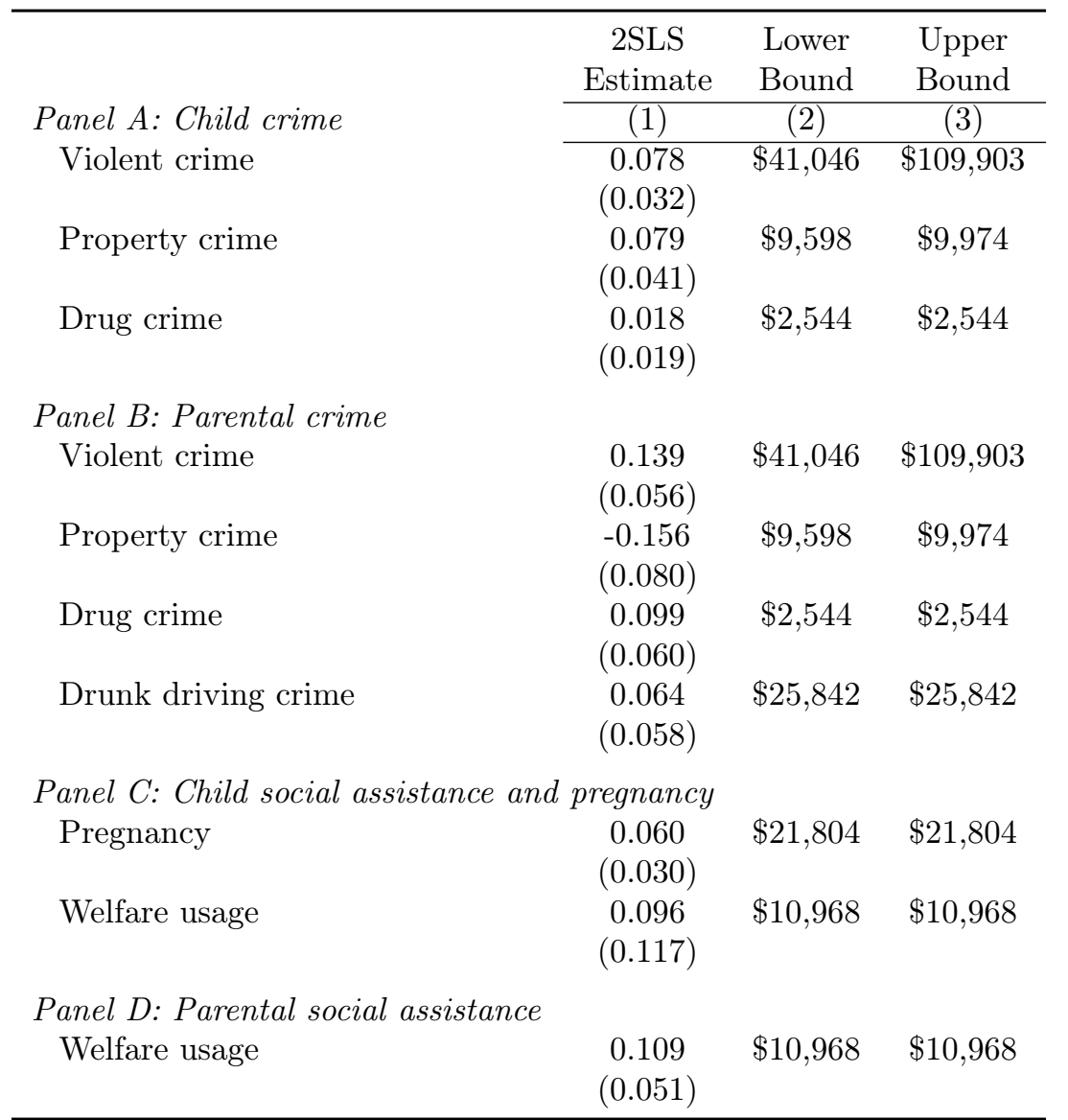

Note: This table reports two-stage least squares coefficients and upper and lower bound social cost of crime estimates. For cost of crime estimates, we use the values presented in Mueller-Smith (2015). To be conservative in our cost estimates, we assume violent crime are assaults, property crime are larceny, and drug crimes are possession. 